\title{
Applications of Microbial Laccases: Patent Review of the Past Decade (2009-2019)
}

\author{
Anastasia Zerva ${ }^{1}\left(\mathbb{D}\right.$, Stefan Simić ${ }^{2}$, Evangelos Topakas ${ }^{1, * \mathbb{D}}$ and Jasmina Nikodinovic-Runic ${ }^{2, *(D)}$ \\ 1 IndBioCat Group, Biotechnology Laboratory, School of Chemical Engineering, National Technical University \\ of Athens, 5 Iroon Polytechniou Str., Zografou Campus, 15780 Athens, Greece; anazer@chemeng.ntua.gr \\ 2 Institute for Molecular Genetics and Genetic Engineering, University of Belgrade; Vojvode Stepe 444a, \\ 11000 Belgrade, Serbia; simic_stefan@outlook.com \\ * Correspondence: vtopakas@chemeng.ntua.gr (E.T.); jasmina.nikodinovic@imgge.bg.ac.rs (J.N.-R.); \\ Tel.: +30-210-772-3264 (E.T.); +381-11-397-60-34 (J.N.-R.)
}

Received: 19 October 2019; Accepted: 30 November 2019; Published: 4 December 2019

\begin{abstract}
There is a high number of well characterized, commercially available laccases with different redox potentials and low substrate specificity, which in turn makes them attractive for a vast array of biotechnological applications. Laccases operate as batteries, storing electrons from individual substrate oxidation reactions to reduce molecular oxygen, releasing water as the only by-product. Due to society's increasing environmental awareness and the global intensification of bio-based economies, the biotechnological industry is also expanding. Enzymes such as laccases are seen as a better alternative for use in the wood, paper, textile, and food industries, and they are being applied as biocatalysts, biosensors, and biofuel cells. Almost 140 years from the first description of laccase, industrial implementations of these enzymes still remain scarce in comparison to their potential, which is mostly due to high production costs and the limited control of the enzymatic reaction side product(s). This review summarizes the laccase applications in the last decade, focusing on the published patents during this period.
\end{abstract}

Keywords: laccase; structure; function; reaction; application; biocatalysis; patent

\section{Introduction}

Laccases ( $p$-benzenediol: oxygen oxidoreductase EC 1.10.3.2) are multicopper-containing oxidases that are able to oxidize a wide range of phenol compounds and amines. The reaction cycle of laccase involves a one-electron substrate oxidation, a four-electron transport to the active site, and the subsequent four-electron reduction of $\mathrm{O}_{2}$ to $\mathrm{H}_{2} \mathrm{O}$.

The first discovered and characterized laccase had a blue color in solution, due to the coordination of one of the copper molecules, but several laccases lacking this property have since been discovered, which are named 'yellow' or 'white' laccases. The spectroscopic properties of laccases have been used in the past for the identification of a polyphenol oxidase as a laccase, together with the substrate specificity of the enzyme, but with the accumulation of data from different enzymes and organisms, it became apparent that 'laccase' is a rather vague term, including a wide range of oxidases with different properties. Together with the rapidly increasing availability of genomic and transcriptomic data, a clear need for specific sequence motifs to identify and annotate laccase genes in genomes have risen. Studies focusing on multiple protein sequence alignments and phylogenetic analysis have tried to fulfill this need, such as the phylogenetic analysis of [1] with 350 multicopper oxidase sequences, the work of [2] for the identification of a set of signature sequences, and the work of [3] correlating protein sequence alignment data with biochemical data regarding the substrate scope of 11 multicopper oxidases. Moreover, the accumulation of data regarding new enzymes and genes over 
the last 20 years created the need for bioinformatics tools and databases that are dedicated to the classification of multicopper oxidases and laccases. One such effort is the LCCED database, (Laccase and Multicopper Oxidase Engineering Database, https://lcced.biocatnet.de/ [4]), where the available sequences for multicopper oxidases are grouped in 16 families.

The presence of laccases is widespread in bacteria, plants, fungi, and insects, which is a strong indication of their involvement in various physiological processes. In plants, laccases participate mostly in lignification, while the fungal counterparts are responsible for the microbial attack on lignin.

The most attractive characteristics of laccases in terms of biotechnological applications are the production of water as a by-product and the low substrate specificity. The substrate range of laccases includes polyphenols, methoxylated phenols, and aromatic amines, as well as inorganic materials [5]. The biotechnological applications of laccases have been the subject of research for more than 30 years, and they cover a wide scope of disciplines, among them electrochemistry, materials science, polymer chemistry, biocatalysis and synthetic chemistry, food chemistry, and others. Laccases can be applied in the food and feed industry, paper and pulp industry, cosmetics and pharmaceuticals industry, textile industry, and many others, but their universal establishment as industrial biocatalysts is still hindered by high production costs and relatively low stability [6].

The aim of the present work is to summarize the laccase applications in the last decade, focusing on the published patents during this period. The enzyme industry is one of the fastest-growing markets worldwide; it was valued at $\$ 7082$ million in 2017, and is projected to reach $\$ 10,519$ million in 2024 at a compound annual growth rate (CAGR) of 5.7\% from 2018 to 2024, while the cost of enzymes for biofuel applications alone should total $\$ 1.0$ billion in 2020, registering a CAGR of $10.4 \%$ [7]. Laccases, due to their applicability in various industrial fields, have the potential to account for a significant part of the global enzyme market. A previous patent review on laccases was published in 2008 [8]; however, in the last 10 years, great progress has been made in the application of laccases in various industrial fields, both at the laboratory scale, but also at the industrial scale, as reflected in the vast numbers of submitted patents. Therefore, the present review aims to summarize the latest patent and literature material through the presentation and discussion of the major innovations and industrial trends.

\section{Occurrence, Properties, and General Aspects of Laccases}

Laccases are ubiquitous enzymes, since their presence spans almost all kingdoms of life, from bacteria and fungi to plants and animals. Therefore, laccases participate in a great variety of physiological processes. In terms of microbial laccases, the bacterial counterparts, such as the model protein CotA from Bacillus subtilis, are usually intracellular, and they are considered to be responsible for the production of dark endospore pigments, aiming at UV and oxidation protection [9]. Laccases, similar to laccase-like multicopper oxidase (LMCO) CueO from E. coli, are associated with copper homeostasis, and they only have a weak phenol oxidase activity [9]. Recently, data are starting to accumulate supporting a certain involvement of bacterial laccases in lignin degradation. For example, activity on small lignin-derived phenolics was shown for small, two-domain laccases from the genus Streptomyces, [10], and from a thermotolerant Thermus sp. laccase [11].

On the other hand, fungal laccases are mainly extracellular, and they are involved in a number of different physiological processes, such as wood degradation and delignification, virulence, pathogenesis, pigmentation, and fruiting body formation [12]. Laccases are widely distributed in fungi, and laccase genes and gene products have been found in basidiomycetes, ascomycetes, and deuteromycetes. Extensive literature is available on laccases from basidiomycetes, especially white-rot fungi [12], while some laccases have also been characterized from ascomycete saprotrophs and ectomycorrhizal species. Many studies focus on lignin degradation and wood modification by laccases, with or without the use of mediators [13-15], and as a result, laccases are now considered essential enzymes in fungal lignocellulose degradation.

Most bacterial laccases are active in a wide range of temperatures and $\mathrm{pH}$ values $\left(30-85^{\circ} \mathrm{C}\right.$ and 3.0-9.0, respectively) [16], but the most extremophilic laccases found so far are of bacterial origin, 
which is a fact of special importance for industrial applications [12]. The $K_{m}$ of bacterial laccases for 2,2'-azino-bis-(3-ethylbenzothiazoline-6-sulphonic acid (ABTS) and 2,6-dimetoxy phenol (2,6-DMP) lies in the micromolar range [16], similar to fungal counterparts [17]. Fungal laccases usually have acidic $\mathrm{pH}$ optima and isoelectric points, while most alkalophilic laccases reported to date are of bacterial origin [16]. The molecular weight of most bacterial laccases can vary from 20 to $80 \mathrm{kDa}$ [16], while for fungal laccases, this range is usually $50-80 \mathrm{kDa}$ [17]. Inhibitors of laccase activity include several metals, EDTA, L-cysteine, azide, cyanide, glutathione, dithiothreitol, and thiourea, among others [18]. Recent data regarding the structural basis of laccase inhibition by metals revealed the binding of chloride and fluoride anions to the T2 copper center, and thus the inhibition of oxygen reduction [19].

\subsection{Structural Aspects, Mode of Action, and Redox Properties of Laccases}

The laccase structure is mostly conserved among all known laccases. At present, 180 structures are available in Protein Data Bank (PDB) corresponding to the keyword 'laccase', while 86 of them have been added after 2015 (Table 1). PDB entries corresponding to the term 'laccase' have been reviewed previously by [9].

Table 1. Laccase entries in PDB after 2015.

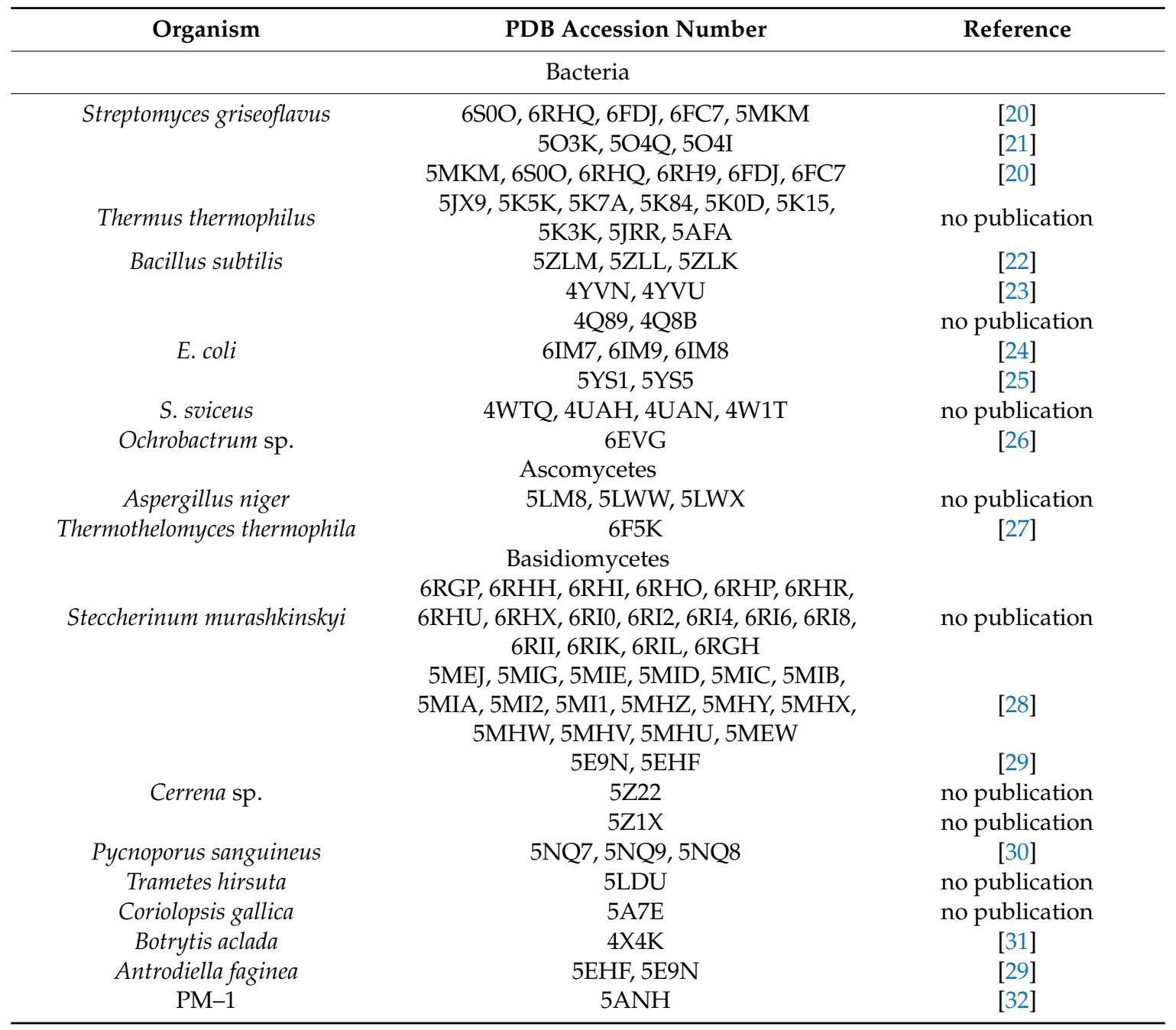

The molecular architecture of most laccases includes three cupredoxin domains with a $\beta$-barrel structure, although laccases with two such domains have been discovered, which are named two-domain or Small Laccases (SLACs, [20]). In a typical structure, a mononuclear copper-binding site $\mathrm{T} 1$ is situated in domain 3 close to the protein surface, and a trinuclear copper-binding site (TNC) 
consisting of one T2 and two T3 copper atoms is formed by the proximity of domains 1 and 3 (Figure 1). Substrate one-electron oxidation takes place in the T1 copper, and the four-electron reduction of $\mathrm{O}_{2}$ to $\mathrm{H}_{2} \mathrm{O}$ occurs in the TNC. The distinction of copper atoms in a laccase molecule is based on spectroscopic data [3]. The topology of the T1 copper-binding site is formed by two His and one Cys equatorial residues in trigonal coordination with the $\mathrm{Cu}$ atom, and two additional weakly- or non-coordinating residues in an axial position [33]. A Met is usually found in one of these axial ligands of low-redox potential $\left(\mathrm{E}_{0}\right)$ (0.3-0.5 V versus normal hydrogen electrode (NHE) bacterial and plant laccases, coordinating to the T1 copper center, in contrast to most fungal ones, which include a Leu or Phe [3,9]. This Met is also observed in the recently solved structure of Thermus thermophilus laccase (5JRR), and to the LMCO CueO (6EVG) from the bacterium Ochrobactrum sp. [26]. The existence of Met as a fourth coordinating axial ligand at the T1 Cu center, or its replacement by a Phe or a Leu, might affect, to a certain extent, the $\mathrm{E}_{0}$ of the enzyme. Laccases with non-coordinating residues at this position generally have higher $\mathrm{E}_{0}$, and they are thus capable of oxidizing a wider array of substrates [33]. For example, high $\mathrm{E}_{0}$ basidiomycete laccases $(0.5-0.8 \mathrm{~V}$ versus $\mathrm{NHE})$ usually have a Phe, and medium $\mathrm{E}_{0}$ ascomycete laccases $(0.4-0.7 \mathrm{~V}$ versus NHE) have Leu $[27,33]$. However, this observation is not to be taken as a general rule, since for example, the $M$. thermophila laccase, containing Leu in this position, has still a lower $\mathrm{E}_{0}$ than B. subtilis CotA laccase [34].

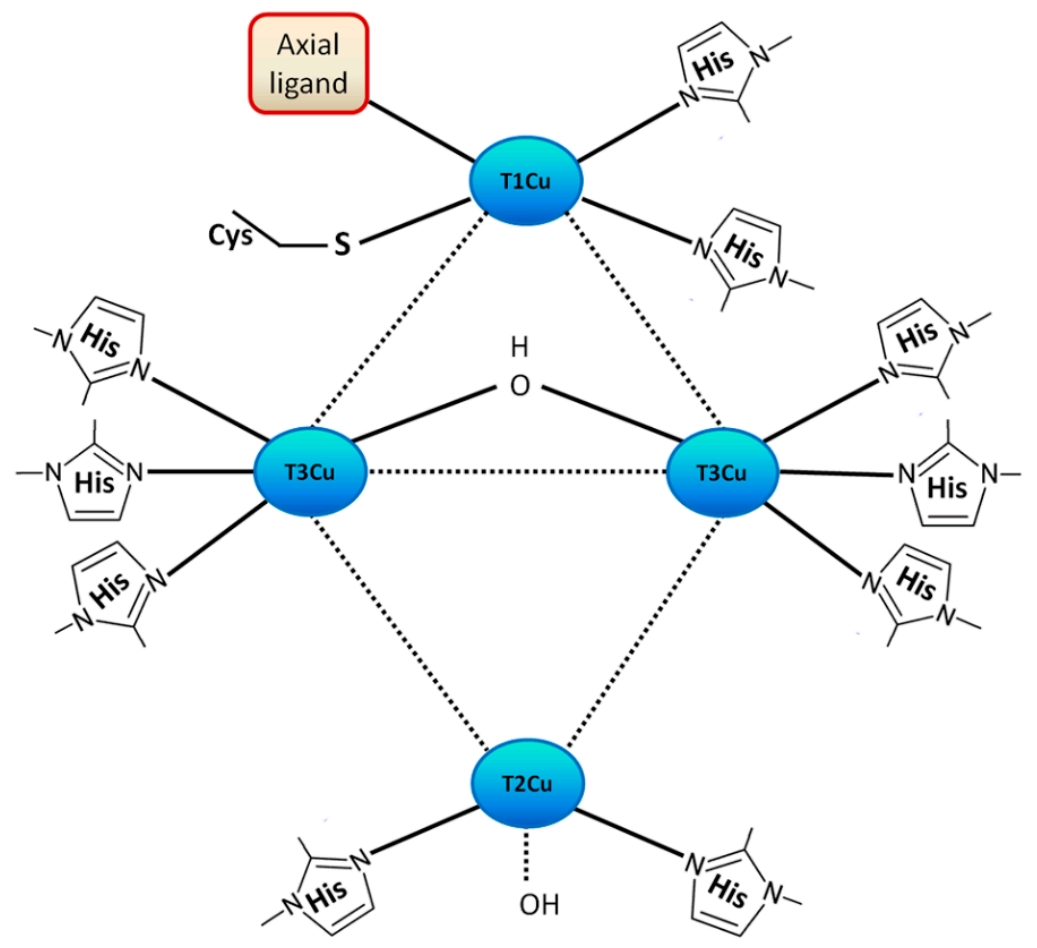

Figure 1. Schematic representation of the copper-binding site architecture in laccases (resting oxidized state). The axial ligand can be either a Met, a Leu or a Phe (see text). Scheme adapted from [18] and [35].

Laccases operate as batteries, storing electrons from individual substrate oxidation reactions to reduce molecular oxygen. The mechanism of $\mathrm{O}_{2}$ reduction was firstly described for low redox potential laccases. As summarized by Jones and Solomon [36], the resting oxidized (RO) form of the enzyme (Figure 1) is reduced by four electrons from a suitable reducing substrate. In the fully reduced state, oxygen is bound to the trinuclear copper center (TNC). A two-electron reduction results in the formation of a peroxide intermediate that is bound between one of the T3 copper ions and a T2 copper ion. A second two-electron reduction results in the cleavage of the $\mathrm{O}-\mathrm{O}$ bond and the release of one water molecule, while the enzyme returns to the fully oxidized state (native intermediate, NI). The $\mathrm{O}_{2}$ reduction mechanism was described only recently for high-redox potential Trametes versicolor 
laccase [35]. The authors supported that the mechanism is essentially the same with low-redox potential laccases, but with a few differences. Contrary to the low-redox potential laccases, in high redox potential laccases, the T1 copper reduction is very fast, and thus, the rate-determining step of the reaction is the intramolecular electron transfer for the reduction of the native intermediate. That is why laccases with $\mathrm{T} 1$ sites that have high redox potential are of special interest in biotechnological processes as bleaching and bioremediation agents.

Nonetheless, the redox potential of a given laccase usually can determine the substrate range that the enzyme is able to oxidize. However, the non-phenolic parts of lignin have redox potentials up to $1.5 \mathrm{~V}$, and therefore cannot be oxidized by laccases. This recalcitrant part of lignin can still be oxidized by laccases with the use of suitable mediators, which are small molecules that are first oxidized by laccases to radicals; then, they attack the substrate through different mechanisms, such as electron or radical hydrogen atom transfer [37]. A wide array of compounds has been used in the literature as mediators, such as 2,2,6,6-tetramethyl-1-piperidinyloxy (TEMPO), ABTS ([14], 1-hydroxybenzotriazole (1-HBT) [38], syringaldehyde, vanillin, $\alpha$-naphthol [39], and others. The laccase-mediator system (LMS) has been used for the removal of residual lignin in biomass [13,40], or the treatment of recalcitrant pollutants, such as antibiotics [39] or other drugs [41], pesticides [42], industrial textile wastewater [43], and even synthetic fragrances [44]. LMS has been also used for the oxidative synthesis of platform chemicals [45].

\subsection{Production of Laccases}

The efficient mass production of laccases for industrial purposes still has to be achieved. Laccase production in an efficient and cost-effective manner has been the focus of many research and industrial efforts through the years. The production of laccases in their native hosts poses many problems regarding the yield and productivity. Especially for high- $\mathrm{E}_{0}$ laccases, which are usually derived from basidiomycetes, the production of enzymes in submerged continuous cultures is hindered by the slow growth rates and the subsequent low productivities. However, technical issues, such as the changes in rheology properties of the culture caused by the fungal growth, also hinder the production of such enzymes. Moreover, the isolation and purification of laccases from the culture broth is a tedious and costly procedure.

Several efforts have been made in order to overcome these issues. For example, the detailed optimization of the culture medium can have a significant effect on the production yields of laccases from white-rot fungi. Schneider et al. [46] used an optimization approach based on a central composite rotatable design to optimize in detail the carbon and nitrogen sources of the medium, aiming at the optimization of laccase production from Marasmiellus palmivorus. The maximum titer obtained was $3420 \mathrm{U} \mathrm{mL}^{-1}$ in a $5 \mathrm{~L}$ tank reactor.

The use of inducers can significantly enhance the production yield, contributing to the feasibility of the process. For example, the induction of laccases from Trametes versicolor with the use of vanillic acid was used as a strategy to increase laccase yield, resulting in almost $590 \mathrm{U} \mathrm{L}^{-1}$ in flasks and $785 \mathrm{U} \mathrm{L}^{-1}$ in an airlift tank reactor [47]. The combination of this approach with the quest for new basidiomycete strains with improved laccase expression profiles was the strategy used by [48]. The authors reported a new strain, Hexagonia hirta, with an improved laccase expression profile. The laccase production, with the use of $\mathrm{Cu}^{2+}$ and 2,5-xylidine as inducers, reached $1944.44 \mathrm{U} \mathrm{ml}^{-1}$ and $5671.30 \mathrm{U} \mathrm{mL}^{-1}$, respectively.

However, the use of inducers can increase greatly the cost of the procedure; therefore, cultivation strategies must be designed, including cheap industrial byproducts as growth media, or as inducers, in order to lower the cost of the overall process. A similar approach was adopted by [49]. The authors used olive oil mill wastewater, supplemented with suitable nitrogen sources, for the growth of Pleurotus citrinopileatus strain, which resulted in a maximum laccase production of $7777.8 \mathrm{U} \mathrm{L}^{-1}$.

Most recently, the same strategy was adopted by [50] for the production of laccase from Ganoderma lucidum in $30 \mathrm{~L}$ bioreactors. The authors used the hemicellulose-rich, beechwood organosolv pretreatment stream as a growth medium for the cultivation and obtained up to $596 \mathrm{U} \mathrm{L}^{-1}$ of 
laccase activity. Economic analysis of the process resulted in a $€ 1.08 \mathrm{kU}^{-1}$ for laccase production from this system, corresponding to a price 78 times lower than the average price of commercially available enzymes.

Over the last 20 years, the tools of DNA manipulation were widely employed in order to tackle these issues. The efforts and challenges related to the heterologous expression of laccases in heterologous hosts have been previously reviewed by [51]. Specifically, for high- $\mathrm{E}_{0}$ basidiomycete laccases, numerous efforts have been made for their production in heterologous hosts, mainly yeasts, such as Saccharomyces cerevisiae and Pichia pastoris, but also filamentous fungi, such as Trichoderma reesei and Aspergillus sp. [52]. Unfortunately, fungal laccases are extremely difficult to obtain in an active form and in sufficient quantity in a heterologous host. The reasons remain unclear to date, but insufficient post-translational modifications, differential glycosylation levels, and codon usage were previously suggested [52]. As a result, the careful optimization of all production parameters must be performed in the heterologous production systems in order to obtain sufficient yields for commercialization. A successful example is the heterologous expression of a Trametes versicolor laccase in Pichia pastoris [53]. After the optimization of several parameters, the laccase titer reached $18,123 \mathrm{U} \mathrm{L}^{-1}$ in a $5 \mathrm{~L}$ tank reactor. The production levels obtained for POXA1b laccase from Pleurotus ostreatus in P. pastoris reached $42 \mathrm{U} \mathrm{mL}^{-1}$ for an inducible expression system and $60 \mathrm{U} \mathrm{mL}^{-1}$ for a constitutive system [54]. $\mathrm{Gu}$ et al. [52] demonstrated the enhanced expression of two laccase isozymes from Coprinus comatus in P. pastoris by fusing an additional 10 amino acid tag at the $N$-terminus. The laccase expression reached 689 and $1465 \mathrm{U} \mathrm{L}^{-1}$, and the authors attributed this expression enhancement to the correct processing of the polypeptide chain by the P. pastoris cells.

The production of bacterial laccases can also be improved by their heterologous expression in eukaryotic hosts, as shown by [55]. The expression of a mutant Bacillus licheniformis LS04 laccase, constructed by site-directed mutagenesis, resulted in 2.1-fold higher activity in P. pastoris, reaching a final titer of $347 \mathrm{U} \mathrm{L}^{-1}$ after process optimization.

\section{Patent Search for Microbial Laccases of the Past Decade}

\subsection{Laccase-Related Patents Analysis}

This review aims to demonstrate the wide and expanding applications of microbial laccases in various industries, with a focus on the patents registered during the past decade. Similar patent reviews were published in 2008 and 2015 covering patents until 2007 and 2013 [8,56] with the current review extending over the years 2008-2019 (patents granted up to 1 October 2019).

Taking the number of patents disclosing laccase-related applications for each year over the past decade (Figure 2) and using three different databases (SciFinder ${ }^{\circledR}$, https://www.ncbi.nlm.nih.gov/ pmc/articles/PMC6148602/), WIPO (World Intellectual Property Organization, https://www.wipo.int), and EPO (European Patent Office, https://www.epo.org), an upward trajectory in the number of laccase-related patent applications is evident in recent years, even including the data for year 2019 that was not complete at the time of analysis. The overall patent count applying 'laccase' search term was 2626, 1238, and 1287, respectively. The additional search limit to the published year was 'Title and Abstract' for SciFinder and 'Front page' for WIPO and EPO. That SciFinder recovered almost double the number of patents suggests the comprehensiveness of this database, as it combines the Chemical Abstracts Service CAS and Medline databases. The average annual number of laccase-related patents was 339 (SciFinder) and 165 and 175 in WIPO and EPO, with maxima in 2016, 2018, and 2015, respectively (Figure 2). The number of scientific literature (books, articles, editorials, thesis) in this same time frame is 4.4-fold times higher in comparison to the number of patents, which suggest that the research interest for this group of enzymes is still high and that possibly the trend of filed patents will maintain a steady incline in years to come. From 2626 patents, almost half (1247) have been filed by the industrial sector, and the top 10 companies have been listed in Figure 3. Each of the specifically mentioned patents within this review is listed in Table S1. 


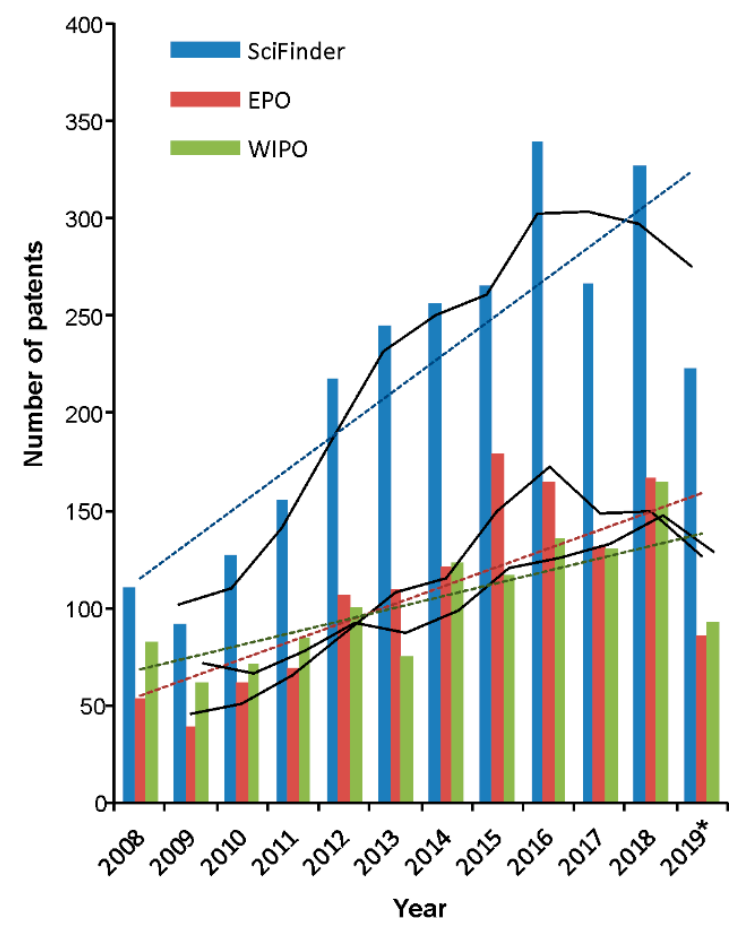

Figure 2. Total number of laccase-related patents registered globally and yearly trend analysis. SciFinder ${ }^{\circledR}$, WIPO (World Intellectual Property Organization), and EPO (European Patent Office) databases were used. * Up to 1 October 2019.

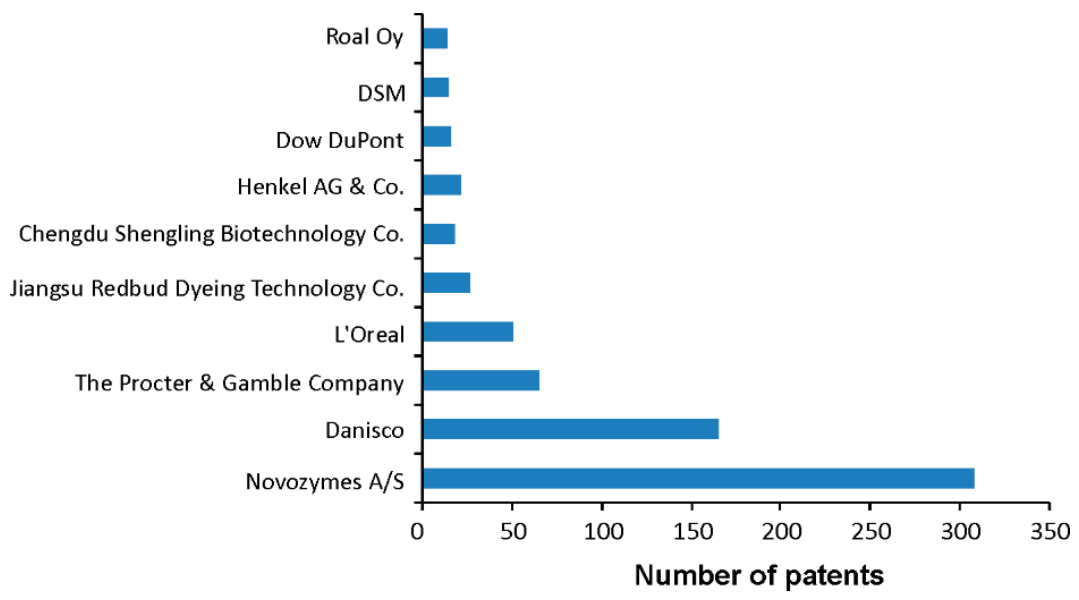

Figure 3. Number of laccase-related patents filed by companies in the 2008-2019 period.

As mentioned, the enzyme market is one of the most fast-growing markets worldwide. Among the top 10 companies that filed laccase-related patents, three of them (Novozymes, Dow DuPont, and DSM) are regarded as major enzyme market players (Figure 3). Apart from the obvious market leader in enzyme production such as Novozymes, Danisco (which is now a member of the DuPont family), a Danish bio-based company with activities in food production, enzymes, and other bioproducts, as well as a wide variety of pharmaceutical grade excipients, is the second one in regard to laccase-related patents covering production improvements and laccases that operate at lower temperatures (WO2019089898A1, US20110302722A1, US20140123404A1). Noteworthy are L'Oreal (Clichy, France) and Jiangsu Redbud Dyeing Technology Co Ltd. (Outer Ring S Rd, Changshu, Suzhou, Jiangsu, China), covering hair dyeing and fiber degumming applications of laccases, respectively (e.g., WO2019072697A1, WO2019046396A1, CN102086533A, CN102517648A) while Shengling Biotechnology Ltd. Co (Yuanji Rd, Yuanlin Township, Changhua County, 51062 Taiwan China) is offering enzymatically 
prepared nutraceuticals. On the other hand, the increasing demand of specific and eco-friendly alternative biocatalysts has encouraged the establishment of small companies offering customized formulations of laccases (e.g., Gecco Biotech). Indeed, major factors driving the enzyme market are the growing diversity in enzyme applications and niche products and more stringent environmental norms curbing the use of chemicals. Health awareness is a factor increasing demand for food quality, safer production processing, and improved environmental impact. Therefore, carbohydrases and proteinases are expected to dominate the enzyme market; however, oxidoreductases, including laccases, are gaining importance due to their increasing usage in food and beverage, textile, and pharmaceutical/cosmetic industries.

Using SciFinder categorization (CA section titles), based on keywords, 10 clear categories were formed (Figure 4) allowing for certain overlap (single patent covering two different applications), and an additional 'miscellaneous' category was formed to cover patents only mentioning laccase as a part of a certain process or application. These categories are similar to the ones recognized in the recent review of the scientific literature regarding laccases by Mate and Alcalde [57]. Patents covering applications in lignin removal and modification are the most frequent, while they are closely followed by patents covering biochemical aspects (identification, directed evolution, expression, fermentation) and biocatalytic applications as well as applications in obtaining bioactive compounds (Pharma/Cosmetics/Agrochemicals) with Bioremediation in fifth place with $10 \%$ of total number of patents in this period. On the other hand, scientific literature concerning the use of laccases for bioremediation was the most abundant (29\%) (Table S2). From this, the application of laccases for larger scale bioremediation or the degradation of waste, particularly plastic waste, can be expected in the near future.

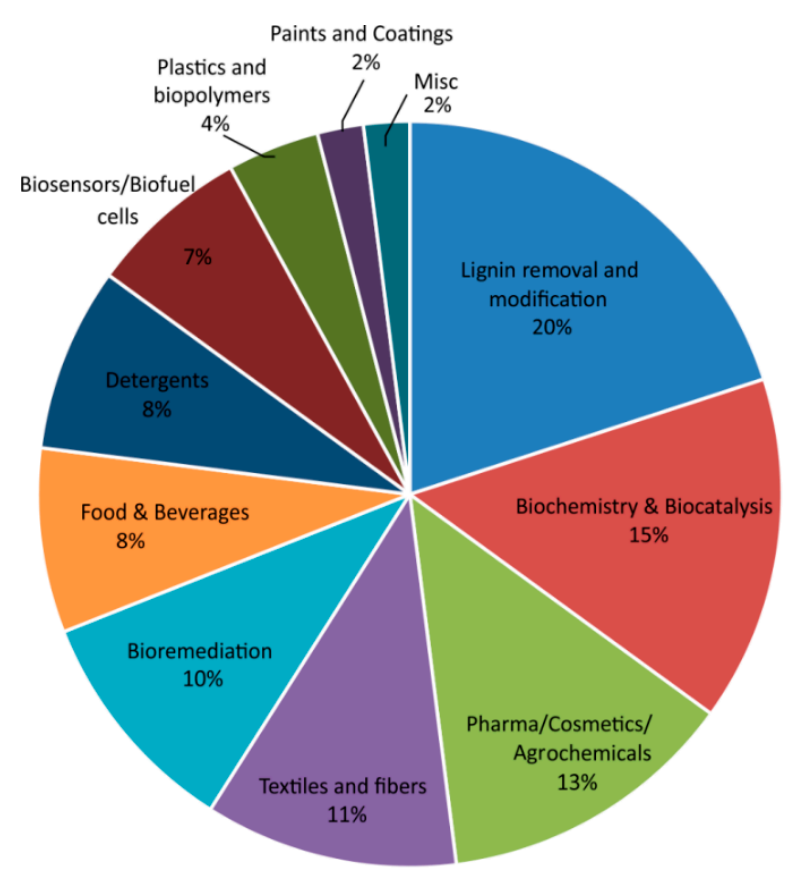

Figure 4. Distribution of 2626 laccase-related patents deposited from 2008-2019 according to the keyword classification and CA section titles of the SciFinder database.

A number of laccases are commercially available (Table 2); however, pilot and industrial-scale applications of laccases are hampered by the high cost of the enzyme, and high cost and the potential toxicity of mediators (if needed). The quality of the enzyme preparation has also been pointed as crucial for both the price and the application [58]. In the study of Osma et al. [59] analyzing the production costs of Tremetes pubescens laccase by wild-type strain, the culture medium was identified as the most significant factor influencing the overall enzyme cost. 
Table 2. Commercially available laccases. ${ }^{a}$

\begin{tabular}{|c|c|c|}
\hline Supplier & $\begin{array}{c}\text { Laccase Origin or Main } \\
\text { Application }\end{array}$ & $\begin{array}{c}\text { Product Catalog Number or } \\
\text { Trade Name }\end{array}$ \\
\hline \multirow{4}{*}{ Sigma-Aldrich (USA) } & Trametes versicolor & 38,429 \\
\hline & Rhus vernicifera (plant laccase) & L2157 \\
\hline & Agaricus bisporus & 40,452 \\
\hline & Myceliophthora thermophila & SAE0050 \\
\hline \multirow{9}{*}{ Creative Enzymes (USA) } & Myceliophthora thermophila & NATE-1592 \\
\hline & Cerrena unicolor & NATE-1578 \\
\hline & Bacillus subtilis & NATE-1570 \\
\hline & Escherichia coli & NATE-1569 \\
\hline & Coriolus versicolor & NATE-0371 \\
\hline & Trametes versicolor & NATE-0374 \\
\hline & Rhus vernicifera (plant laccase) & NATE-0373 \\
\hline & Pleurotus ostreatus & NATE-0372 \\
\hline & Agaricus bisporus & NATE-0370 \\
\hline Jena Bioscience (Germany) & Trametes versicolor & EN-204L \\
\hline United States Biological (USA) & Trametes versicolor & L0850 \\
\hline GECCO Biotech (The Netherlands) & Bacillus licheniformis & - \\
\hline Novozymes A/S (Denmark) & Brewing & Flavourstar \\
\hline Novozymes A/S (Denmark) & Cork production & Suberase \\
\hline Novozymes A/S (Denmark) & Wood pulp delignification & Novozym $^{\circledR} 51003$ \\
\hline Novozymes A/S (Denmark) & Fabric bleaching & DeniLiteI and II \\
\hline Novozymes A/S (Denmark) & Fabric finishing & Novoprime Base 268 \\
\hline Americos Industries Inc. (India) & Fabric bleaching & Americos laccase $\mathrm{P}$ \\
\hline Americos Industries Inc. (India) & Fabric bleaching & Americos laccase LTC \\
\hline Apollo Chemical Co, LLC (USA) & Fabric bleaching & APCOZYME II-S \\
\hline $\mathrm{Ab}$ Enzymes GmbH (Germany) & Fabric finishing & Ecostone LC10 \\
\hline Amano Enzyme USA Co. Ltd. & $\begin{array}{l}\text { Color enhancement in food } \\
\text { products }\end{array}$ & LACCASE Y120 \\
\hline Genencor Inc. (USA) & Fabric bleaching & Primagreen Base LT100 \\
\hline Genencor Inc. (USA) & Fabric finishing & IndiStar \\
\hline Genencor International Inc. & Fabric bleaching & PrimaGreen EcoFade LT100 \\
\hline Season Chemicals (China) & Fabric bleaching & Bleach Cut 3-S \\
\hline Lignozym GmbH (Germany) & Wood pulp bleaching & Lignozym ${ }^{\circledR}$-process \\
\hline Zytex Pvt. Ltd. (India) & Fabric bleaching & ZyLite \\
\hline Puridet Asia Ltd. (Hong Kong) & Fabric bleaching & Purizyme \\
\hline Tri-Tex Co. Inc. (Canada) & Fabric bleaching & Trilite II \\
\hline Proenzimas Ltd. (Colombia) & Fabric bleaching & Lacasa Ultratex \\
\hline Condor Speciality Products (USA) & Fabric bleaching & Hypozyme \\
\hline Sunson Industry Group Co. (China) & Fabric bleaching & Prozyme ${ }^{\circledR}$ LAC \\
\hline Colotex Biotechnology Co.(China) & Fabric finishing & Cololacc BB \\
\hline DyStar GmbH (Germany) & Fabric finishing & Lava ${ }^{\circledR}$ Zyme LITE \\
\hline
\end{tabular}

${ }^{a}$ Data was obtained and gathered by analyzing the main enzyme suppliers for the laccases or from the review of literature regarding the major industrial applications of laccases.

\subsection{Laccase Production and Improvement}

One of the major patent groups within the last decade is dealing with the identification, recombinant expression, and enzyme improvement through directed evolution, fermentation conditions, and immobilization.

The relative uniformity of most of laccase's properties might pose some issues in regard to their utilization in specific applications. For example, the low solvent tolerance of most laccases might be an impediment for their biocatalytic applications, since the water solubility of most phenolic substrates is rather low, and the use of organic solvents is desirable. Moreover, most laccases known to date have acidic $\mathrm{pH}$ optima, which can prohibit their use in systems operating at alkaline conditions. A few examples of such processes are lignocellulose pretreatment for ethanol production, hair coloring, textile dyeing, and human body implants [60]. The two most popular approaches to these issues are the discovery of novel enzymes with desired properties, and genetic engineering for the modification of the properties of known counterparts. 
Regarding the operation in alkaline conditions, a few native laccases have been reported to be active in a broad $\mathrm{pH}$ range. Most recently, a laccase from Sporothrix carnis was described, with $\mathrm{pH}$ optimum at 7 , a broad $\mathrm{pH}$ stability profile, and satisfactory stability in the presence of various solvents [61]. A novel white laccase from Myrothecium verrucaria was shown to be stable over alkaline $\mathrm{pH}$ [62] and effective at the delignification of agroindustrial residues. Regarding bacterial counterparts, a bacterial laccase from Bacillus subtilis was described by Kumar et al. [63], operating optimally at $\mathrm{pH} 8.5$ and maintaining the activity for $24 \mathrm{~h}$ at $55^{\circ} \mathrm{C}$. The authors demonstrated the polymerization of various phenolic compounds by the enzyme toward a large variety of different hair dyes. A second laccase with satisfactory activity in alkaline conditions and significant tolerance in high salt concentrations was isolated from a Bacillus sp. strain [64]. Moreover, a novel laccase gene was isolated from a marine metagenomic library [65], and the corresponding enzyme was found to be stable in a wide temperature range and in the presence of organic solvents. The laccase was applied successfully to the decolorization of different dyes.

Tailoring the laccase catalytic properties by rational design and directed evolution has been carried out as well, which has often been guided by computational simulations. Scheiblbrandner et al. [66], by employing a directed evolution approach, detected the amino acid residues close to the T1 copper-binding site, which play a major role in the performance of the laccase from Botrytis aclada in alkaline conditions. Thus, they obtained mutants with fivefold higher specific activities at $\mathrm{pH}$ 7.5. Yin et al. [60] succeeded at shifting the $\mathrm{pH}$ optimum of Lcc9 from Coprinopsis cinerea to $\mathrm{pH}>8.0$ by a directed evolution approach. The double mutant was shown to have improved performance in the decolorization of indigo dye. With the same method, an evolved Myceliophthora thermophila laccase was obtained and applied at the synthesis of $\mathrm{C}-\mathrm{N}$ heteropolymeric dyes at $\mathrm{pH} 9$ [67]. A knowledge-gaining directed evolution approach was employed for the design of a Melanocarpus albomyces laccase mutant [68], bearing two amino acid substitutions close to the T1 copper-binding site. The mutant was shown to have a threefold improved turnover number at $\mathrm{pH}$ 9.8. Rasekh et al. [69] managed to improve the stability of Bacillus sp. laccase in the presence of organic solvents by introducing hydrophobic residues to the surface of the protein. The chimeric laccase from parent Pycnoporus cinnabarinus and Coriolopsis sp. laccases also showed improved stability in organic solvents [70]. The GreeDo and Lc OB-1 mutants of fungal laccase were obtained by combining computational design and directed evolution methods; these are recent examples of the improvement of activity and stability in high redox potential laccases [71,72]. Furthermore, a computational methodology accumulating beneficial interactions between a laccase and a target substrate has proved to be useful through a repurposing strategy to design a novel polar-binding scaffold to anchor negatively charged groups to POXA1b laccase [73]. Within recent patents regarding laccase producing strains and/or mutants are the ones covering high-producing mutant strains of Myrothecium verrucaria such as strain $3 \mathrm{H} 6$ with laccase yields of $3409 \mathrm{U} \mathrm{L}^{-1}$, representing improvement of $55.6 \%$ in comparison to that of the wild-type strain (CN109868224A). Similarly, at least a threefold increase in laccase yield from $T$. versicolor was reported as a consequence of applying ultrasound during the fermentation process (CN108285894A). Additionally, the improvement of enzyme properties is commonly addressed, such as with a S208G/F227A double mutant of CotA laccase with improved catalytic efficiency, thermal stability, and tolerance to alkaline environments (CN109439635A). These efforts are also represented by the production of recombinant laccase by construct formation including the Phanerochaete chrysosporium laccase gene, where the recombinant enzyme showed $39 \%$ higher activity compared to the bacterial enzyme (CN108018295A). On the other side, more and more patents are covering the methods to immobilize and/or recycle laccases (CN109652386A; KR20190033780A). Interestingly, silica, and more recently graphene, carbon nanotubes, and nano zirconium have been suggested as suitable laccase carriers (CN 107988196A, KR20180041065A, CN107858344A). However, natural materials such as bacterial nanocellulose (TWI622646B20180501) and diatoms have also been covered in the patents (CN105063008A). Along the lines of lowering costs and resource intensity, a report presenting the use 
of raw materials in the liquid medium during laccase production was described. The authors used agricultural by-products such as shaddock peel for this purpose (CN106119215A).

\section{Major Applications of Microbial Laccases}

\subsection{Lignin Removal and Modification}

Lignin is an irregular polyphenolic polymer synthesized by a polymerization of phenyl propanoid units, namely coniferyl alcohol, sinapyl alcohol, and coumaryl alcohol [74]. During the papermaking process, the fibrous raw material (most commonly wood) is converted into pulp, which is subsequently converted to paper. The pulping process serves to remove non-cellulosic material from raw fiber, one of which is lignin [75]. Conventionally, pulping is done either mechanically by the grinding of raw material against an abrasive surface or chemically by acid (Sulfite) or alkaline (Kraft) processes. The former requires large amounts of electrical energy and produces paper that turns yellow and brittle over time, and the latter produces lower pulp yields with the drawback of requiring large amounts of water and producing toxic waste [6]. Plant laccases play an important role in the lignification of cell walls, and the primary role of laccases in microorganisms, especially white-rot fungi, is considered to be the degradation of plant lignin. As such, they were found to be highly promising for the paper production process-from the initial biopulping, biobleaching, delignification, and biografting of the pulp fibers to the deinking of recycled paper and the treatment of industrial effluents. Recent advances in the delignification of paper and pulp have been reviewed by Singh and Arya [6]. The authors pointed out that there are several bottlenecks at present for the industrial application of laccases to this sector, the most important of which are related to the cost of mediators and enzyme production.

Significant research efforts have been devoted to the depolymerization or modification of lignin by microbial laccases in the past 20 years. The highest numbers of patents regarding laccases within the last decade fall into the category of lignin removal and modification (Figure 4). This is partially due to the intensive research and development efforts in the implementation of the concept of integrated biorefineries based on lignocellulosic biomass globally from 2010 [76,77]. Both processes, lignin removal and modification, now aim at the production of either small compounds as novel chemical building blocks, or at the development of new biomass-based materials. Recent examples include the production of benzaldehyde compounds and vanillin from lignin [78], the development of lignin-based controlled-release fertilizers [79], and the improvement of antioxidant activity of lignin [80], but also the modification of pulp for wood fiber insulation boards manufacturing [81]. Indeed, recent patents regarding the use of laccases in the paper industry are mostly dedicated to the incremental improvements of the established processes either through the addition of chemical mediators or the improved laccase variants (CN108823177A, CN109098025A). Some of the beneficial aspects of laccase use in papermaking, which were outlined previously in this paragraph, were also mirrored in the patent literature, with reports in the pulping process (CN107653726A, CN108442162A). Improvement of the properties of wastepaper was also a notable field of application in the patent literature, where laccases offer less fiber loss, higher whiteness, and an overall improved reusability of paper (CN105178084A, CN105133409A). The bioremediation utility of laccase in the paper industry was showcased by the treatment of chlorine bleaching effluent in combination with the salen complexes of different transition metals (CN106045004A).

\subsection{Biocatalysis}

The use of laccases in organic synthesis (biocatalysis) is another field of application for these biotechnologically relevant enzymes. This application has been grouped with patents dealing with biochemical aspects of the laccases (Figure 4) including the identification of novel ones, recombinant expression, and directed evolution, which are covered in Section 3.2. A wide range of different compounds has been synthesized by laccase-mediated oxidation, with or without the use of mediators. These include phenolics, antibiotics, oligomers or polymers, and others. A recent review regarding 
the biocatalytic synthesis of bioactive compounds by laccases was written by Kudanga et al. [82], and previously, a thorough review of laccase applications in organic synthesis was presented by Mogharabi and Faramarzi [83]. Recent synthetic efforts include the direct synthesis of furans from aliphatic diallyl ethers through a chemoenzymatic metathesis/aromatization cascade [84], the oxidation of 4-hydroxy-chalcones [85,86], the coupling of coumarins with acetone [87], the whole-cell catalyzed oxidation of 1,4-dihydropyridines [88], a sustainable iodination of phenols [89], the coupling of 4-phenylurazole with a number of aromatic compounds [90], the synthesis of triaminated cyclohexa-2,4-dienones from catechol [91], the synthesis of ferulic acid and ethyl ferulate derivatives [92], hydroxycinnamoyl peptides from ferulic acid and carnosine [93], coumestan derivatives [94], iodinated phenolic compounds [95], caffeic acid dimers [96], ferulic, sinapic, coumaric acid, and $-\mathrm{OH}$ dilignol dimers [97], and the oxidation of thioethers to sulfoxides [98]. In WO 2016050988A1, a chemoenzymatic preparation of biphenyl compounds by oxidative coupling is described, and similarly, a synthesis of binaphthyl compounds was reported in CN101418321A. In an additional relevant example, naturally occurring flavonolignan silybin was synthesized by the oxidation of the taxifolin and coupling with coniferyl alcohol (CN105400843A). Among non-phenolic natural products, indole alkaloids catharanthine and vindoline were coupled in a procedure involving laccase catalysis (EP2135872A1) (Table S1).

\subsection{Pharma/Cosmetics/Agrochemicals}

Applications of laccases in medicinal chemistry have shown their presence as an emerging field for their application, including the development of antibiotics, anticancer drugs, antifungal drugs, sedatives, and in detoxifying the toxic compounds [99]. Namely, due to their ability to transform a wide range of organic compounds, laccases have been reported to catalyze the synthesis of a number of biologically active molecules. Among recent reports, a set of 2,6-dimethoxy-4(phenylimino)cyclohexa-2,5-dienones was synthesized by T. versicolor laccase-catalyzed oxidative coupling, and their activity against Botrytis cinerea phytopathogen was assessed [100]. Likewise, a series of 1,4-naphthoquinone-2,3-bis-sulfides, synthesized with the aid of Novozym ${ }^{\circledR} 51003$ (M. thermophila laccase expressed in Aspergillus oryzae) catalysis, showed activity against melanoma (UACC62), prostate (PC3), breast (MCF7), and renal (TK10) cancer cell lines, with some compounds having $\mathrm{IC}_{50}$ values under $10 \mu \mathrm{M}$ [101]. The laccase-catalyzed dimerization products of caffeic acid [96] and sinapyl alcohol [102] were shown to possess antioxidant activity.

Interestingly, apart from acting as catalysts in the synthesis of biologically active molecules, laccases were investigated as potential therapeutics themselves. A recent example of such an investigation concluded that crude and purified Pseudomonas putida LUA15.1 laccase preparations inhibited the mycelial growth and morphology of six fungal pathogens [103]. In a report predating the former, laccase from a white rot fungus Abortiporus biennis demonstrated activity against Hep G2 and MCF-7 cells with $\mathrm{IC}_{50}$ values of $12.5 \mu \mathrm{M}$ and $6.7 \mu \mathrm{M}$, respectively, as well as inhibitory activity against HIV-1 reverse transcriptase [104].

A significant fraction of cosmetic applications of laccase is concerned with hair dyeing products. Permanent hair dyes are typically formed by the combination of the primary intermediate ( $p$-phenylenediamine, $p$-aminophenol, and their derivatives), the coupler ( $m$-phenylenediamines, resorcinol, naphthols, and derivatives), and hydrogen peroxide, along with ammonia. The oxidant serves two main purposes: to oxidize the primary intermediates and, in combination with ammonia, to lighten the natural hair color [105]. However, these conditions enable side reactions with hair proteins and cause hair damage. Therefore, replacing hydrogen peroxide by another oxidant such as laccase may diminish this effect. Applications of alkaline laccases for this purpose have been reported $[63,106]$. The ability of laccase to degrade melanin has also been proposed for skin-whitening applications [107].

A method for preparing hyaluronic acid substitute by oxidizing chitosan with laccase-TEMPO system was covered by a patent from 2015 (CN104745662A). Additionally, examples of laccases-aided extraction of a bioactive molecule are present, such as in CN109260300A, where it improved the 
extraction of schizandronic acid from Schisandra chinensis. An interesting pharmaceutical application of laccase is described in the patent US20190060471A1, where laccase is mixed into a pill containing opiate alkaloids in order to prevent potential drug abuse. Namely, attempts to extract alkaloids for misuse result in their oxidation by laccase, eliminating or lowering their detrimental effect.

\subsection{Textiles and Fibers}

The first commercial laccase-based product used in the textile industry was DeniLite ${ }^{\circledR}$, which was launched by Novozymes in 1996 as an environmentally more benign alternative to previously used denim-bleaching agents such as sodium hypochlorite. Afterwards, numerous commercial products based on laccase were released onto the market for the purpose of denim bleaching $[58,108]$. Laccases were shown to degrade the textile dye indigo, yielding isatin and subsequently anthranilic acid, enabling both the bleaching of indigo-dyed denim as well as the treatment of indigo-contaminated wastewater [109]. Numerous investigations of textile dye wastewater treatment by laccases were also reported, which is reflected in recent journal publications including immobilized [110-112] as well as non-immobilized laccases $[60,113]$. Apart from wastewater treatment applications, laccases were recently investigated in wool dyeing by the polymerization of syringic acid [114], the antimicrobial coating of textile fibers by polymerization of catechol and p-phenylenediamine [115], the $\mathrm{pH}$-responsive and conducting coating of wool fabrics by the polymerization of diaminobenzenesulfonic acid [116], nylon and wool dyeing by laccase-catalyzed 1,4-dihydroxybenzene, 2,7-dihydroxynapthalene, and 2,5-diaminobenzenesulphonic acid coupling [117].

Another major field of laccase application in the textile industry is cotton bleaching, the purpose of which is to obtain a white appearance of the fiber. In order to obtain a high degree of whiteness, the conventional bleaching process of cellulosic fiber materials included consequential treatment with sodium hypochlorite and hydrogen peroxide. The use of laccase as an alternative for this purpose was proposed as a means of decreasing the chemical, energy, and water consumption of the process [118]. Since the presence of flavonoids in cotton is the main cause of its color, the laccase-promoted bleaching likely occurs via the oxidation of phenolic groups of flavonoids [119]. Examples from the recent patent literature outline the flaws of conventional cotton bleaching techniques, requiring high temperature, alkaline conditions, and high water and energy consumption. The alternatively proposed laccase-containing cotton pretreatement formulations enable low-temperature operating conditions and lower waste production (CN109722908A, CN108642854A). Apart from cotton treatment, textile-related patents report laccase as a polymerization catalyst for fiber dye precursors, enabling low-cost and environmentally benign methods for textile dyeing (CN108978270A, CN103952927A). The application of laccase in the antibacterial finishing of fibers has also been the topic of numerous patent reports. Among those are examples of grafting beta-cyclodextrin on fiber surfaces by laccase/TEMPO oxidation (CN108893982A, CN105951436A).

\subsection{Bioremediation and Detoxification}

As mentioned, laccases exhibit broad substrate specificity, enabling them to oxidize a broad range of xenobiotic compounds including chlorinated phenols, bisphenols, and polycyclic aromatic hydrocarbons that are persistent in the environment and known to have carcinogenic and mutagenic effects [120]. A significant part of the research effort on laccases has been devoted to their ability to degrade a variety of environmental pollutants, and this category of patents is similar in number to the patents regarding applications in textile industry, while in the recent literature review, bioremediation was the category with the most scientific articles (about 30\%, as found by [57]). A few examples are dyes, antibiotics, pesticides, fertilizers, endocrine-disrupting chemicals, and many others. The literature regarding these experimental efforts has been recently reviewed by Bilal et al. [121] and Barrios-Estrada et al. [122]. In the recent literature, examples of the degradation of pesticides [123], synthetic dyes [124], bisphenol A [125], and pharmaceuticals [126] can be found. Additionally, a report of partial polyethylene degradation by Bacillus sp. YP1 laccase was published in the patent literature. The authors 
report the oxyfunctionalization of the polyethylene surface upon laccase treatment (CN103980535B, CN103980535A).

More recently, laccases found application in coal biosolubilization (clean coal technologies). For example, the Fusarium oxysporum LOCK 1134 strain efficiently biosolubilizes lignite, and the liquefied coal can be modified further by laccase to release humic and fulvic acids [127]. They have also been marked to play a crucial role in polyethylene (PE) degradation along with oxidoreductases and alkane hydroxylases after either biotic or abiotic initiation [128], and there are patents covering this application of laccases, including thermophilic laccase from Brevibacillus and its use in compositions for the biodegradation of plastics (WO2014167562A1) or enzymes immobilized on mesoporous magnetic nanoparticles and their use for polymer degradation (WO2012122437A2).

\subsection{Food and Beverages}

The ability of laccase to transform substrates possessing the phenol moiety was likewise applied in the production of food and beverages. Numerous applications of laccases in beverage production concern a two-step phenol-removal process. The first step is the induction of phenolic complexes by laccases, and during the second step, the polymerized polyphenolic compounds are adsorbed onto a membrane. A number of patents have been reported to employ laccases for the stabilization of beverages including beer, wine, and juice [129]. The laccase-induced crosslinking of biopolymers was shown to be beneficial in the baking industry as well. For example, the crosslinking of ferulic acid and arabinoxylan catalyzed by Trametes hirsuta laccase increased the maximum resistance of dough and decreased the dough extensibility of flour and gluten doughs, resulting in increased bread softness and volume [130,131] (WO2019201725A1). The applications of laccase-catalyzed crosslinking were also reported in the crosslinking of whey-protein isolate and vanillic acid for potential emulsifying applications [132], as well as the crosslinking of peanut proteins, causing a modulation of the immune response to those proteins in vivo [133].

Recent patents cover the application of laccases in the improvement of the nutritional quality of animal feed such as distillers dried grains (WO2019055455A1) or wild pepper meal pig feed (CN 109221615A).

\subsection{Detergents}

The detergent industry occupies a significant portion of the global enzyme market. The application of enzymes in detergents enhances the detergents' ability to remove persistent stains with the benefit of making detergents more environmentally benign. The enzymes most commonly encountered in detergent formulations are proteases, amylases, cellulases, and lipases [134]. Although not common in commercial detergents, laccases have been reported in detergent formulations in the recent patent literature (CN104263544A). Namely, stains originating from strongly colored fruit and vegetables typically contain various flavonoids (such as anthocyanins), which are susceptible to laccase-catalyzed oxidation. This notion has led to an application of laccase for detergent power improvement (US20180127687A1). Another report concerns the application of laccase as a dye transfer inhibitor, meaning that it serves to prevent the unwanted dyeing of fabric by dye transfer from another fabric during the washing process (US20170267947A1), (US2017267947A1). The presence of laccase in a detergent for biofilm removal, for medical instrument cleaning, has likewise been reported in the patent literature (CA2892497A1). On the other side, the complex enzyme detergent containing at least one laccase for the cane sugar manufacturing industry with high heat resistance has also been patented (CN109321553A).

\subsection{Sensors and Biofuel Cells}

Laccase-based biosensors have been reviewed by Rodríguez-Delgado et al. [135] and most recently by Castrovilli et al. [136]. Laccases are used for the development of biosensors for the detection of 
catechol [137], dopamine [138], polyphenols [139], 17 $\beta$-estradiol [140], pharmaceutical residues [141], and others.

The development of biofuel cells aims at the sustainable production of electrical energy through chemical reactions, which were mediated by oxidoreductases. There is no conceptual difference between conventional fuel cells and enzymatic biofuel cells; however, the latter can operate at near-neutral $\mathrm{pH}$ and ambient temperature. Additionally, using enzymes as electrocatalysts has advantages including specificity toward their substrates, renewability, biodegradability, high turnover frequencies, and low intrinsic overvoltages [142]. Laccases have been used in the cathode of such devices for the oxygen reduction reaction (ORR), with well-known benefits such as low overpotential and the possibility of direct electron transfer [143-145]. Recent reports of laccase applications in biofuel cells include the directed evolution of the E. coli CueO multicopper oxidase, with the improved variant (D439T/L502K) having a significantly increased onset potential compared to the wild-type enzyme [146]. Likewise, the K316 N/D500G mutant of Bacillus licheniformis CotA laccase was shown to catalyze the oxygen reduction at the fuel cell cathode from $0.59 \mathrm{~V}$ (SHE) and $\mathrm{pH} 8$ [147]. A fuel cell containing laccase on both the cathode and the anode was described as well. The laccase-catalyzed oxidation of bisphenol A served as the anode reaction, while the conventional laccase-mediated oxygen reduction served as the cathode reaction [148]. Patents exemplifying laccase-based sensors are numerous and are usually covering the method of their preparation such as the preparation of a two-dimensional nano rare earth borate laccase sensor and its application (CN103499625A) or specific applications such as cancer diagnostics (CN110068570A). Likewise, the patent literature contains numerous applications of laccase in biofuel cells, commonly utilizing laccase for the cathode reaction. Examples include a starch/oxygen biofuel cell, where laccase is grafted onto the cathode, and E. coli displaying saccharifying enzymes where glucose dehydrogenase is grafted on the anode, enabling the use of biomass as fuel (CN106450399A).

\subsection{Plastics and Biopolymers}

The ability of laccases to promote the oxidative coupling of aromatic compounds such as phenols and anilines served as the basis for the production of various types of functional polymers. Among those is the conductive polymer polyaniline (PANI), the laccase-mediated synthesis of which was outlined in a recent review [149]. The atom transfer radical polymerization of $N$-vinylimidazole catalyzed by $T$. versicolor laccase showcased its ability to produce a polymer with a well-defined molecular mass and potential applications in drug and gene delivery, fuel cell membranes, and polyionic liquids [150]. Another laccase-mediated polymerization in a highly controlled manner produced alternating copolymers of catechol and xylylenediamines with potential applications as imaging agents [151]. A recent report showcased the ability of laccase to catalyze the polymerization of dopamine, yielding a more uniform and stable polydopamine homopolymer compared to the one obtained by conventional methods [152]. Furthermore, laccases have been employed in the synthesis of biomacromolecular assemblies such as tyrosine-tagged crosslinked proteins with promising biomedical applications $[153,154]$. Recent laccase-related patents within this application field are covering inventions such as the production of protein/polysaccharide composite film using thermostable recombinant bacteria laccase or methods for preparing seals for automobile instrument panels (CN109111584A, CN109096736A) (Table S1).

The application of laccases in the field of biopolymers extends also to the grafting of different compounds to polymers or the functionalization of polymers. Toward this end, numerous efforts have been made, including the functionalization of pectin with ferulic acid derivatives [155], the functionalization of wool through caffeic acid 'zip' polymerization [156], and the production of 6-carboxylate chitooligosaccharides as a superabsorbent material [157]. The modification of lignocellulosic polymers can lead to materials with superior properties, such as the modification of jute fibers by octadecylamine grafting for enhancing the hydrophobic character of the material [158]. Depending on the choice of laccase substrate, properties such as improved strength properties, increased antimicrobial resistance, or hydrophilicity/hydrophobicity can be imparted to lignocellulosic materials. 
Regarding the manufacturing of novel materials, the production of chitin nanocrystals [159], of arabinoxylan and glucomannan aerogels [160], the polymerization of dopamine [152], the dimerization of 2,6-dimethoxyphenol [161], the oligomerization of 4-hydroxybenzoic acid [162] for the improvement of the anti-fouling properties of membranes, and the polymerization of catechol and gallic acid [163] have been recently reported. Catechol polymerization has been used as an example for Su et al. [164] to comment on the effect of reaction conditions on the nature of the final product.

\subsection{Paints and Coatings}

Laccases have been widely applied to the synthesis of novel dyes with the aim to develop greener routes for their industrial production. These research efforts have been most recently reviewed by Polak and Jarosz-Wilkolazka [165]. Since then, numerous studies were published, reporting the synthesis of hair dyes [63], phenoxazine derivatives [166], benzene- and naphthalene-derived non-toxic dyes [167], 2,5-diaminobenzenesulfonic acid (2,5-DABSA) and catechol [67] or resorcinol [168] coupling derivatives, several aminoindamine and indoaniline dyes for hair dyeing and cosmetics applications [169], and even a dye for protein gel staining [170]. Moreover, the dyeing of fabrics by the in situ polymerization of phenol and amine compounds has been reported $[115,171]$. These are also covered in patents dealing with the preparation of paper-based lacquer paintings (CN109627825A), oxygen scavenger coating composition (US2009226996A1), or thermal insulation coatings for exterior walls (CN109735175A)).

Recently, a coating liquid suitable for coating food packing paper was patented and contains laccase-grafted modified chitosan and an antibacterial palm wax emulsion. The coating liquid showed excellent steam barrier properties coupled with antibacterial activity (CN107190574A).

\subsection{Nanobiotechnology and Biomedicine}

Laccase's application in biomedicine, to a great extent, is based on their biocatalytic properties, aiming at the manufacturing of novel materials for biomedical applications. As mentioned earlier, the production of hydrogels or aerogels is a sector where laccases can be of value for the production of biocompatible materials. The grafting of phenol compounds to poly (vinyl alcohol) (PVA) films can lead to the formation of antimicrobial biocompatible materials with numerous biomedical applications [172]. A suitable example is the laccase-mediated production of a ferulic acid-crosslinked poly (vinyl alcohol) (PVA) hydrogel for application in ophthalmology [173]. The laccase/TEMPO-mediated grafting of silk fibroin onto bacterial cellulose was shown to enhance the biocompatibility of the membrane [174]. The laccase/TEMPO oxidation of galactomannans led to the production of an aerogel with satisfactory drug delivery properties [175]. Similar materials were also obtained by the laccase oxidation of fenugreek gum [176]. Chitosan hydrogels with laccase-oxidized phenolics as crosslinkers showed improved swelling properties and suitable biocompatibility as well as conductive gels based on chitosan and hyaluronic acid [177], (CN104725657A).

The potential laboratory applications of laccases also extend to the field of nanotechnology in regard to the synthesis and/or modification of nanomaterials for various sectors. The development of enzymatically oxidized lignin nanosized colloidal particles for various applications was recently reported [178], as well as the synthesis of hybrid nanoflowers containing laccase as a nanobiocatalyst for the degradation of dyes (CN104789549A, CN105536691A) [179]. For example, the technical problems that were encountered in the application of laccases for xenobiotics removal, such as their low biodegradability and removal rate, was solved by adsorption of laccase to carbon nanotubes, resulting in enhanced enzyme activity, as well as thermophilic and psychrophilic stability (CN109912048A).

The anticancer activity of $T$. versicolor laccase immobilized on Pluronic ${ }^{\circledR}$-stabilized silver nanoparticles has also been demonstrated recently [180]. A review covering the medicinal properties of basidiomycete laccases can also be found [181]. 


\section{Conclusions-Future Challenges}

The industrial uses of laccases still seem limited compared to their potential. Research should be focused on reducing the production cost and on developing the tools to better control the reaction on selected polyphenols and other substrates to be treated by these enzymes.

The major challenges concerning the industrial use of laccases include the production costs, but also the broad substrate specificity of laccases. While the wide substrate spectrum of laccases can be a significant advantage for biodegradation applications, it can also pose a problem to their commercial application in the field of biocatalysis due to by-product formation following free radical chemistry. Moreover, the broad substrate specificity of laccases is a drawback in the field of biosensor manufacturing. Biosensors, especially when used for biomedical applications, require a high degree of selectivity toward the target compound that cannot yet be achieved by most commercially available laccases. Combined with the high production costs, the need for the discovery or engineering of novel enzymes with preferred characteristics seems imperative. The literature regarding laccase production costs is sparse; therefore, more research is needed on the development of the production processes.

Aside from the described fields of application and the respective challenges, the research interest on laccases is far from declining. Recently, new areas of application continue to emerge, including the degradation of plastics, the development of diagnostic tools, and others. Therefore, it might be safe to assume that the numbers of filed patents will continue to increase in the years to come. Consequently, laccases will find their way to an ever-increasing number of industrial fields, and possibly will be used to replace traditional processes toward greener production routes.

Supplementary Materials: The following are available online at http://www.mdpi.com/2073-4344/9/12/1023/s1, Table S1: The patents cited in the main text. Table S2: Comparison of recent laccase-related journal publications and patents across categories.

Author Contributions: J.N.-R. and E.T. conceived the outline of the review and, along with A.Z. and S.S., selected the material. All authors contributed to the writing of the paper.

Funding: This project was partially funded by the Ministry of Education, Science and Technological Development of Republic of Serbia project no. 173048, and by the Hellenic Foundation for Research and Innovation (HFRI) and the General Secretariat for Research and Technology (GSRT), under the grant No. 1085, "Novel Conversion Technologies of Waste Biomass to Food additives and Fine Chemicals".

Conflicts of Interest: The authors declare no conflict of interest.

\section{References}

1. Hoegger, P.J.; Kilaru, S.; James, T.Y.; Thacker, J.R.; Kues, U. Phylogenetic comparison and classification of laccase and related multicopper oxidase protein sequences. FEBS J. 2006, 273, 2308-2326. [CrossRef]

2. Kumar, S.V.S.; Phale, P.S.; Durani, S.; Wangikar, P.P. Combined sequence and structure analysis of the fungal laccase family. Biotechnol. Bioeng. 2003, 83, 386-394. [CrossRef]

3. Reiss, R.; Ihssen, J.; Richter, M.; Eichhorn, E.; Schilling, B.; Thöny-Meyer, L. Laccase versus laccase-like multi-copper oxidase: A comparative study of similar enzymes with diverse substrate spectra. PLoS ONE 2013, 8, e65633. [CrossRef]

4. Sirim, D.; Wagner, F.; Wang, L.; Schmid, R.D.; Pleiss, J. The Laccase Engineering Database: A classification and analysis system for laccases and related multicopper oxidases. Database 2011, bar006. [CrossRef]

5. Mehra, R.; Muschiol, J.; Meyer, A.S.; Kepp, K.P. A structural-chemical explanation of fungal laccase activity. Sci. Rep. 2018, 8, 17285. [CrossRef]

6. Singh, G.; Arya, S.K. Utility of laccase in pulp and paper industry: A progressive step towards the green technology. Int. J. Biol. Macromol. 2019, 134, 1070-1084. [CrossRef]

7. Lopes, A.M.; Ferreira Filho, E.X.; Moreira, L.R.S. An update on enzymatic cocktails for lignocellulose breakdown. J. Appl. Microbiol. 2018, 125, 632-645. [CrossRef]

8. Kunamneni, A.; Plou, F.J.; Ballesteros, A.; Alcalde, M. Laccases and their applications: A patent review. Recent Pat. Biotechnol. 2008, 2, 10-24. [CrossRef]

9. Hakulinen, N.; Rouvinen, J. Three-dimensional structures of laccases. Cell Mol. Life Sci. 2015, 72, 857-868. [CrossRef] 
10. Majumdar, S.; Lukk, T.; Solbiati, J.O.; Bauer, S.; Nair, S.K.; Cronan, J.E.; Gerlt, J.A. Roles of small laccases from Streptomyces in lignin degradation. Biochemistry 2014, 53, 4047-4058. [CrossRef]

11. Navas, L.E.; Martinez, F.D.; Taverna, M.E.; Fetherolf, M.M.; Eltis, L.D.; Nicolau, V.; Estenoz, D.; Campos, E.; Benintende, G.B.; Berretta, M.F. A thermostable laccase from Thermus sp. 2.9 and its potential for delignification of Eucalyptus biomass. AMB Express 2019, 9, 24. [CrossRef]

12. Yang, J.; Li, W.; Ng, T.B.; Deng, X.; Lin, J.; Ye, X. Laccases: Production, expression regulation, and applications in pharmaceutical biodegradation. Front. Microbiol. 2017, 8, 832. [CrossRef]

13. Longe, L.F.; Couvreur, J.; Leriche Grandchamp, M.; Garnier, G.; Allais, F.; Saito, K. Importance of mediators for lignin degradation by fungal laccase. ACS Sustain. Chem. Eng. 2018, 6, 10097-10107. [CrossRef]

14. Munk, L.; Andersen, M.L.; Meyer, A.S. Influence of mediators on laccase catalyzed radical formation in lignin. Enzym. Microb. Technol. 2018, 116, 48-56. [CrossRef]

15. Munk, L.; Sitarz, A.K.; Kalyani, D.C.; Mikkelsen, J.D.; Meyer, A.S. Can laccases catalyze bond cleavage in lignin? Biotechnol. Adv. 2015, 33, 13-24. [CrossRef]

16. Chauhan, P.S.; Goradia, B.; Saxena, A. Bacterial laccase: Recent update on production, properties and industrial applications. 3 Biotech. 2017, 7, 323. [CrossRef]

17. Baldrian, P. Fungal laccases-occurrence and properties. FEMS Microbiol. Rev. 2006, 30, 215-242. [CrossRef]

18. Agrawal, K.; Chaturvedi, V.; Verma, P. Fungal laccase discovered but yet undiscovered. Bioresour. Bioprocess. 2018, 5, 4. [CrossRef]

19. Polyakov, K.M.; Gavryushov, S.; Fedorova, T.V.; Glazunova, O.A.; Popov, A.N. The subatomic resolution study of laccase inhibition by chloride and fluoride anions using single-crystal serial crystallography: Insights into the enzymatic reaction mechanism. Acta Crystallogr. Sect. D 2019, 75, 804-816. [CrossRef]

20. Gabdulkhakov, A.; Kolyadenko, I.; Kostareva, O.; Mikhaylina, A.; Oliveira, P.; Tamagnini, P.; Lisov, A.; Tishchenko, S. Investigations of accessibility of T2/T3 copper center of two-domain laccase from Streptomyces griseoflavus Ac-993. Int. J. Mol. Sci. 2019, 20, 3184. [CrossRef]

21. Gabdulkhakov, A.G.; Kostareva, O.S.; Kolyadenko, I.A.; Mikhaylina, A.O.; Trubitsina, L.I.; Tishchenko, S.V. Incorporation of copper ions into T2/T3 centers of two-domain laccases. Mol. Biol. (Mosc.) 2018, 52, $29-35$. [CrossRef]

22. Xie, T.; Liu, Z.; Wang, G. Structural insight into the allosteric coupling of Cu1 site and trinuclear Cu cluster in CotA laccase. ChemBioChem. 2018, 19, 1502. [CrossRef]

23. Liu, Z.; Xie, T.; Zhong, Q.; Wang, G. Crystal structure of CotA laccase complexed with 2,2-azinobis-(3-ethylbenzothiazoline-6-sulfonate) at a novel binding site. Acta Crystallogr. Sect. F 2016, 72, 328-335. [CrossRef]

24. Sana, B.; Chee, S.M.Q.; Wongsantichon, J.; Raghavan, S.; Robinson, R.C.; Ghadessy, F.J. Development and structural characterization of an engineered multi-copper oxidase reporter of protein-protein interactions. J. Biol. Chem. 2019, 294, 7002-7012. [CrossRef]

25. Wang, H.; Liu, X.; Zhao, J.; Yue, Q.; Yan, Y.; Gao, Z.; Dong, Y.; Zhang, Z.; Fan, Y.; Tian, J.; et al. Crystal structures of multicopper oxidase CueO G304K mutant: Structural basis of the increased laccase activity. Sci. Rep. 2018, 8. [CrossRef]

26. Granja-Travez, R.S.; Wilkinson, R.C.; Persinoti, G.F.; Squina, F.M.; Fulop, V.; Bugg, T.D.H. Structural and functional characterisation of multi-copper oxidase $\mathrm{CueO}$ from lignin-degrading bacterium Ochrobactrum sp. reveal its activity towards lignin model compounds and lignosulfonate. FEBS J. 2018, 285, 1684-1700. [CrossRef]

27. Ernst, H.A.; Jorgensen, L.J.; Bukh, C.; Piontek, K.; Plattner, D.A.; Ostergaard, L.H.; Larsen, S.; Bjerrum, M.J. A comparative structural analysis of the surface properties of asco-laccases. PLoS ONE 2018, 13, e0206589. [CrossRef]

28. Polyakov, K.M.; Gavryushov, S.; Ivanova, S.; Fedorova, T.V.; Glazunova, O.A.; Popov, A.N.; Koroleva, O.V. Structural study of the X-ray-induced enzymatic reduction of molecular oxygen to water by Steccherinum murashkinskyi laccase: Insights into the reaction mechanism. Acta Crystallogr. D Struct. Biol. 2017, 73, 388-401. [CrossRef]

29. Glazunova, O.A.; Polyakov, K.M.; Moiseenko, K.V.; Kurzeev, S.A.; Fedorova, T.V. Structure-function study of two new middle-redox potential laccases from basidiomycetes Antrodiella faginea and Steccherinum murashkinskyi. Int. J. Biol. Macromol. 2018, 118, 406-418. [CrossRef] 
30. Orlikowska, M.; de J Rostro-Alanis, M.; Bujacz, A.; Hernandez-Luna, C.; Rubio, R.; Parra, R.; Bujacz, G. Structural studies of two thermostable laccases from the white-rot fungus Pycnoporus sanguineus. Int. J. Biol. Macromol. 2018, 107, 1629-1640. [CrossRef]

31. Osipov, E.M.; Polyakov, K.M.; Tikhonova, T.V.; Kittl, R.; Dorovatovskii, P.V.; Shleev, S.V.; Popov, V.O.; Ludwig, R. Incorporation of copper ions into crystals of T2 copper-depleted laccase from Botrytis aclada. Acta Crystallogr. Sect. F 2015, 71, 1465-1469. [CrossRef]

32. Pardo, I.; Santiago, G.; Gentili, P.; Lucas, F.; Monza, E.; Medrano, F.J.; Galli, C.; Martínez, A.T.; Guallar, V.; Camarero, S. Re-designing the substrate binding pocket of laccase for enhanced oxidation of sinapic acid. Catal. Sci. Technol. 2016, 6, 3900-3910. [CrossRef]

33. Sitarz, A.K.; Mikkelsen, J.D.; Meyer, A.S. Structure, functionality and tuning up of laccases for lignocellulose and other industrial applications. Crit. Rev. Biotechnol. 2016, 36, 70-86. [CrossRef]

34. Zeng, J.; Zhu, Q.; Wu, Y.; Lin, X. Oxidation of polycyclic aromatic hydrocarbons using Bacillus subtilis CotA with high laccase activity and copper independence. Chemosphere 2016, 148, 1-7. [CrossRef]

35. Sekretaryova, A.; Jones, S.M.; Solomon, E.I. O2 Reduction to water by high potential Multicopper Oxidases: Contributions of the T1 Copper Site Potential and the Local Environment of the trinuclear copper cluster. J. Am. Chem. Soc. 2019, 141, 11304-11314. [CrossRef]

36. Jones, S.M.; Solomon, E.I. Electron transfer and reaction mechanism of laccases. Cell Mol. Life Sci. 2015, 72, 869-883. [CrossRef]

37. Hilgers, R.; Vincken, J.P.; Gruppen, H.; Kabel, M.A. Laccase/Mediator Systems: Their Reactivity toward Phenolic Lignin Structures. ACS Sustain. Chem. Eng. 2018, 6, 2037-2046. [CrossRef]

38. Raj, K.; Krishnan, C. Improved high solid loading enzymatic hydrolysis of low-temperature aqueous ammonia soaked sugarcane bagasse using laccase-mediator system and high concentration ethanol production. Ind. Crops Prod. 2019, 131, 32-40. [CrossRef]

39. Navada, K.K.; Kulal, A. Enzymatic degradation of chloramphenicol by laccase from Trametes hirsuta and comparison among mediators. Int. Biodeterior. Biodegrad. 2019, 138, 63-69. [CrossRef]

40. Feng, N.; Guo, L.; Ren, H.; Xie, Y.; Jiang, Z.; Ek, M.; Zhai, H. Changes in chemical structures of wheat straw auto-hydrolysis lignin by 3-hydroxyanthranilic acid as a laccase mediator. Int. J. Biol. Macromol. 2019, 122, 210-215. [CrossRef]

41. Apriceno, A.; Astolfi, M.L.; Girelli, A.M.; Scuto, F.R. A new laccase-mediator system facing the biodegradation challenge: Insight into the NSAIDs removal. Chemosphere 2019, 215, 535-542. [CrossRef]

42. Bilal, M.; Iqbal, H.M.N.; Barceló, D. Persistence of pesticides-based contaminants in the environment and their effective degradation using laccase-assisted biocatalytic systems. Sci. Total Environ. 2019, 695, 133896. [CrossRef]

43. Guan, Z.B.; Shui, Y.; Song, C.M.; Zhang, N.; Cai, Y.J.; Liao, X.R. Efficient secretory production of CotA-laccase and its application in the decolorization and detoxification of industrial textile wastewater. Environ. Sci. Pollut. Res. 2015, 22, 9515-9523. [CrossRef]

44. Vallecillos, L.; Sadef, Y.; Borrull, F.; Pocurull, E.; Bester, K. Degradation of synthetic fragrances by laccase-mediated system. J. Hazard. Mater. 2017, 334, 233-243. [CrossRef]

45. Wang, K.F.; Liu, C.L.; Sui, K.Y.; Guo, C.; Liu, C.Z. Efficient catalytic oxidation of 5-hydroxymethylfurfural to 2,5-furandicarboxylic acid by magnetic laccase catalyst. ChemBioChem 2018, 19, 654-659. [CrossRef]

46. Schneider, W.D.H.; Fontana, R.C.; Mendonça, S.; de Siqueira, F.G.; Dillon, A.J.P.; Camassola, M. High level production of laccases and peroxidases from the newly isolated white-rot basidiomycete Marasmiellus palmivorus VE111 in a stirred-tank bioreactor in response to different carbon and nitrogen sources. Process. Biochem. 2018, 69, 1-11. [CrossRef]

47. Wang, K.F.; Hu, J.H.; Guo, C.; Liu, C.Z. Scale-up laccase production from Trametes versicolor stimulated by vanillic acid. Bioprocess. Biosyst. Eng. 2016, 39, 1041-1049. [CrossRef]

48. Kandasamy, S.; Muniraj, I.K.; Purushothaman, N.; Sekar, A.; Sharmila, D.J.S.; Kumarasamy, R.; Uthandi, S. High Level Secretion of Laccase $(\mathrm{LccH})$ from a Newly Isolated White-Rot Basidiomycete, Hexagonia hirta MSF2. Front. Microbiol. 2016, 7, 707. [CrossRef]

49. Zerva, A.; Zervakis, G.I.; Christakopoulos, P.; Topakas, E. Degradation of olive mill wastewater by the induced extracellular ligninolytic enzymes of two wood-rot fungi. J. Environ. Manag. 2017, 203, 791-798. [CrossRef] 
50. Lú-Chau, T.A.; Martínez-Patiño, J.C.; Gullón, B.; García-Torreiro, M.; Moreira, M.T.; Lema, J.M.; Eibes, G. Scale-up and economic analysis of the production of ligninolytic enzymes from a side-stream of the organosolv process. J. Chem. Technol. Biotechnol. 2018, 93, 3125-3134. [CrossRef]

51. Piscitelli, A.; Pezzella, C.; Giardina, P.; Faraco, V.; Giovanni, S. Heterologous laccase production and its role in industrial applications. Bioeng. Bugs 2010, 1, 252-262. [CrossRef]

52. Gu, C.; Zheng, F.; Long, L.; Wang, J.; Ding, S. Engineering the expression and characterization of two novel laccase isoenzymes from Coprinus comatus in Pichia pastoris by fusing an additional ten amino acids tag at N-terminus. PLoS ONE 2014, 9, e93912. [CrossRef]

53. Li, Q.; Pei, J.; Zhao, L.; Xie, J.; Cao, F.; Wang, G. Overexpression and characterization of laccase from Trametes versicolor in Pichia pastoris. Appl. Biochem. Microbiol. 2014, 50, 140-147. [CrossRef]

54. Pezzella, C.; Giacobelli, V.G.; Lettera, V.; Olivieri, G.; Cicatiello, P.; Sannia, G.; Piscitelli, A. A step forward in laccase exploitation: Recombinant production and evaluation of techno-economic feasibility of the process. J. Biotechnol. 2017, 259, 175-181. [CrossRef]

55. Wang, J.; Lu, L.; Feng, F. Combined strategies for improving production of a thermo-alkali stable laccase in Pichia pastoris. Electron. J. Biotechnol 2017, 28, 7-13. [CrossRef]

56. Pezzella, C.; Guarino, L.; Piscitelli, A. How to enjoy laccases. Cell Mol. Life Sci. 2015, 72, 923-940. [CrossRef]

57. Mate, D.M.; Alcalde, M. Laccase: A multi-purpose biocatalyst at the forefront of biotechnology. Microb. Biotechnol. 2017, 10, 1457-1467. [CrossRef]

58. Kaczmarek, M.B.; Kwiatos, N.; Szczęsna-Antczak, M.; Bielecki, S. Laccases—Enzymes with an unlimited potential. Biotechnol. Food Sci. 2017, 81, 41-70.

59. Osma, J.F.; Toca-Herrera, J.L.; Rodriguez-Couto, S. Cost analysis in laccase production. J. Environ. Manag. 2011, 92, 2907-2912. [CrossRef]

60. Yin, Q.; Zhou, G.; Peng, C.; Zhang, Y.; Kües, U.; Liu, J.; Xiao, Y.; Fang, Z. The first fungal laccase with an alkaline $\mathrm{pH}$ optimum obtained by directed evolution and its application in indigo dye decolorization. AMB Express 2019, 9, 151. [CrossRef]

61. Olajuyigbe, F.M.; Fatokun, C.O. Biochemical characterization of an extremely stable pH-versatile laccase from Sporothrix carnis CPF-05. Int. J. Biol. Macromol. 2017, 94, 535-543. [CrossRef]

62. Agrawal, K.; Bhardwaj, N.; Kumar, B.; Chaturvedi, V.; Verma, P. Process optimization, purification and characterization of alkaline stable white laccase from Myrothecium verrucaria ITCC-8447 and its application in delignification of agroresidues. Int. J. Biol. Macromol. 2019, 125, 1042-1055. [CrossRef]

63. Kumar, D.; Kumar, A.; Sondhi, S.; Sharma, P.; Gupta, N. An alkaline bacterial laccase for polymerization of natural precursors for hair dye synthesis. 3 Biotech. 2018, 8, 182. [CrossRef]

64. Siroosi, M.; Amoozegar, M.A.; Khajeh, K. Purification and characterization of an alkaline chloride-tolerant laccase from a halotolerant bacterium, Bacillus sp. strain WT. J. Mol. Catal. B Enzym. 2016, 134, 89-97. [CrossRef]

65. Yang, Q.; Zhang, M.; Zhang, M.; Wang, C.; Liu, Y.; Fan, X.; Li, H. Characterization of a novel, cold-adapted, and thermostable laccase-like enzyme with high tolerance for organic solvents and salt and potent dye decolorization ability, derived from a marine metagenomic library. Front. Microbiol. 2018, 9, 2998. [CrossRef]

66. Scheiblbrandner, S.; Breslmayr, E.; Csarman, F.; Paukner, R.; Führer, J.; Herzog, P.L.; Shleev, S.V.; Osipov, E.M.; Tikhonova, T.V.; Popov, V.O.; et al. Evolving stability and pH-dependent activity of the high redox potential Botrytis aclada laccase for enzymatic fuel cells. Sci. Rep. 2017, 7, 13688. [CrossRef]

67. Vicente, A.I.; Viña-Gonzalez, J.; Santos-Moriano, P.; Marquez-Alvarez, C.; Ballesteros, A.O.; Alcalde, M. Evolved alkaline fungal laccase secreted by Saccharomyces cerevisiae as useful tool for the synthesis of C-N heteropolymeric dye. J. Mol. Catal. B Enzym. 2016, 134, 323-330. [CrossRef]

68. Novoa, C.; Dhoke, G.V.; Mate, D.M.; Martínez, R.; Haarmann, T.; Schreiter, M.; Eidner, J.; Schwerdtfeger, R.; Lorenz, P.; Davari, M.D.; et al. KnowVolution of a fungal laccase toward alkaline pH. ChemBioChem 2019, 20, 1458-1466. [CrossRef]

69. Rasekh, B.; Khajeh, K.; Ranjbar, B.; Mollania, N.; Almasinia, B.; Tirandaz, H. Protein engineering of laccase to enhance its activity and stability in the presence of organic solvents. Eng. Life Sci. 2014, 14, 442-448. [CrossRef]

70. Pardo, I.; Rodríguez-Escribano, D.; Aza, P.; de Salas, F.; Martínez, A.T.; Camarero, S. A highly stable laccase obtained by swapping the second cupredoxin domain. Sci. Rep. 2018, 8, 15669. [CrossRef] 
71. Aleksejeva, O.; Mateljak, I.; Ludwig, R.; Alcalde, M.; Shleev, S. Electrochemistry of a high redox potential laccase obtained by computer-guided mutagenesis combined with directed evolution. Electrochem. Commun. 2019, 106, 106511. [CrossRef]

72. Mateljak, I.; Monza, E.; Lucas, M.F.; Guallar, V.; Aleksejeva, O.; Ludwig, R.; Leech, D.; Shleev, S.; Alcalde, M. Increasing redox potential, redox mediator activity, and stability in a fungal laccase by computer-guided mutagenesis and directed evolution. ACS Catal. 2019, 9, 4561-4572. [CrossRef]

73. Giacobelli, V.G.; Monza, E.; Fatima Lucas, M.; Pezzella, C.; Piscitelli, A.; Guallar, V.; Sannia, G. Repurposing designed mutants: A valuable strategy for computer-aided laccase engineering-The case of POXA1b. Catal. Sci. Technol. 2017, 7, 515-523. [CrossRef]

74. Sannigrahi, P.; Pu, Y.; Ragauskas, A. Cellulosic biorefineries-Unleashing lignin opportunities. Curr. Opin. Environ. Sustain. 2010, 2, 383-393. [CrossRef]

75. Bajpai, P. Basic Overview of Pulp and Paper Manufacturing Process. In Green Chemistry and Sustainability in Pulp and Paper Industry; Springer: Cham, Switzerland, 2015. [CrossRef]

76. Roth, S.; Spiess, A.C. Laccases for biorefinery applications: A critical review on challenges and perspectives. Bioprocess. Biosyst. Eng. 2015, 38, 2285-2313. [CrossRef]

77. Perlack, R.; Wright, L.; Turhollow, A. Biomass as Feedstock for a Bioenergy and Bioproducts Industry: The Technical Feasibility of a Billion-Ton Annual Supply; The United States Department of Energy: Washington, DC, USA, 2005.

78. Yang, Y.; Song, W.Y.; Hur, H.G.; Kim, T.Y.; Ghatge, S. Thermoalkaliphilic laccase treatment for enhanced production of high-value benzaldehyde chemicals from lignin. Int. J. Biol. Macromol. 2019, 124, 200-208. [CrossRef]

79. Legras-Lecarpentier, D.; Stadler, K.; Weiss, R.; Guebitz, G.M.; Nyanhongo, G.S. Enzymatic Synthesis of 100\% Lignin Biobased Granules as Fertilizer Storage and Controlled Slow Release Systems. ACS Sustain. Chem. Eng. 2019, 7, 12621-12628. [CrossRef]

80. Li, Z.; Zhang, J.; Qin, L.; Ge, Y. Enhancing Antioxidant Performance of Lignin by Enzymatic Treatment with Laccase. ACS Sustain. Chem. Eng. 2018, 6, 2591-2595. [CrossRef]

81. Schubert, M.; Ruedin, P.; Civardi, C.; Richter, M.; Hach, A.; Christen, H. Laccase-catalyzed surface modification of thermo-mechanical pulp (TMP) for the production of wood fiber insulation boards using industrial process water. PLoS ONE 2015, 10. [CrossRef]

82. Kudanga, T.; Nemadziva, B.; Le Roes-Hill, M. Laccase catalysis for the synthesis of bioactive compounds. Appl. Microbiol. Biotechnol. 2017, 101, 13-33. [CrossRef]

83. Mogharabi, M.; Faramarzi, M.A. Laccase and laccase-lediated lystems in the lynthesis of organic compounds. Adv. Synth. Catal. 2014, 356, 897-927. [CrossRef]

84. Risi, C.; Zhao, F.; Castagnolo, D. Chemo-enzymatic metathesis/aromatization cascades for the synthesis of furans: Disclosing the aromatizing activity of laccase/TEMPO in oxygen-containing heterocycles. ACS Catal. 2019, 9, 7264-7269. [CrossRef]

85. Grosso, S.; Radaelli, F.; Fronza, G.; Passarella, D.; Monti, D.; Riva, S. Studies on the Laccase-Catalyzed Oxidation of 4-Hydroxy-Chalcones. Adv. Synth. Catal. 2019, 361, 2696-2705. [CrossRef]

86. Zerva, A.; Koutroufini, E.; Kostopoulou, I.; Detsi, A.; Topakas, E. A novel thermophilic laccase-like multicopper oxidase from Thermothelomyces thermophila and its application in the oxidative cyclization of 2',3,4-trihydroxychalcone. New Biotechnol. 2019, 49, 10-18. [CrossRef] [PubMed]

87. Wang, Y.F.; Xu, H.; Feng, L.; Shen, X.F.; Wang, C.; Huo, X.K.; Tian, X.G.; Ning, J.; Zhang, B.J.; Sun, C.P.; et al. Oxidative coupling of coumarins catalyzed by laccase. Int. J. Biol. Macromol. 2019, 135, 1028-1033. [CrossRef]

88. Simić, S.; Jeremic, S.; Djokic, L.; Božić, N.; Vujčić, Z.; Lončar, N.; Senthamaraikannan, R.; Babu, R.; Opsenica, I.M.; Nikodinovic-Runic, J. Development of an efficient biocatalytic system based on bacterial laccase for the oxidation of selected 1,4-dihydropyridines. Enzym. Microb. Technol. 2020, 132, 109411. [CrossRef]

89. Sdahl, M.; Conrad, J.; Braunberger, C.; Beifuss, U. Efficient and sustainable laccase-catalyzed iodination of p-substituted phenols using KI as iodine source and aerial O2 as oxidant. RSC Adv. 2019, 9, 19549-19559. [CrossRef]

90. Chen, Y.J.; Zhang, G.Y.; He, Y.H.; Guan, Z. Aryl C-H amination initiated by laccase-mediated oxidation of 4-phenylurazole. Catal. Sci. Technol. 2019, 9, 4216-4221. [CrossRef] 
91. Wellington, K.W.; Govindjee, V.P.; Steenkamp, P. A laccase-catalysed synthesis of triaminated cyclohexa-2,4-dienones from catechol. J. Catal. 2018, 368, 306-314. [CrossRef]

92. Aljawish, A.; Chevalot, I.; Jasniewski, J.; Paris, C.; Scher, J.; Muniglia, L. Laccase-catalysed oxidation of ferulic acid and ethyl ferulate in aqueous medium: A green procedure for the synthesis of new compounds. Food Chem. 2014, 145, 1046-1054. [CrossRef]

93. Aljawish, A.; Chevalot, I.; Madad, N.; Paris, C.; Muniglia, L. Laccase mediated-synthesis of hydroxycinnamoyl-peptide from ferulic acid and carnosine. J. Biotechnol. 2016, 227, 83-93. [CrossRef] [PubMed]

94. Qwebani-Ogunleye, T.; Kolesnikova, N.I.; Steenkamp, P.; de Koning, C.B.; Brady, D.; Wellington, K.W. A one-pot laccase-catalysed synthesis of coumestan derivatives and their anticancer activity. Bioorganic Med. Chem. 2017, 25, 1172-1182. [CrossRef] [PubMed]

95. Ihssen, J.; Schubert, M.; Thony-Meyer, L.; Richter, M. Laccase catalyzed synthesis of iodinated phenolic compounds with antifungal activity. PLoS ONE 2014, 9, e89924. [CrossRef] [PubMed]

96. Nemadziva, B.; Le Roes-Hill, M.; Koorbanally, N.; Kudanga, T. Small laccase-catalyzed synthesis of a caffeic acid dimer with high antioxidant capacity. Process. Biochem. 2018, 69, 99-105. [CrossRef]

97. Perna, V.; Agger, J.W.; Holck, J.; Meyer, A.S. Multiple Reaction Monitoring for quantitative laccase kinetics by LC-MS. Sci. Rep. 2018, 8, 8114. [CrossRef] [PubMed]

98. Rostami, A.; Mohammadi, B.; Shokri, Z.; Saadati, S. Laccase-TEMPO as an efficient catalyst system for metaland halogen-free aerobic oxidation of thioethers to sulfoxides in aqueous media at ambient conditions. Catal. Commun. 2018, 111, 59-63. [CrossRef]

99. Pankaj, K.C.; Shashi, L.B.; Chandana, S. Laccases in pharmaceutical chemistry: A comprehensive appraisal. Mini Rev. Org. Chem. 2016, 13, 430-451.

100. Castro, P.; Mendoza, L.; Vásquez, C.; Pereira, P.C.; Navarro, F.; Lizama, K.; Santander, R.; Cotoras, M. Antifungal Activity against Botrytis cinerea of 2,6-Dimethoxy-4-(phenylimino)cyclohexa-2,5-dienone Derivatives. Molecules 2019, 24, 706. [CrossRef]

101. Wellington, K.W.; Kolesnikova, N.I.; Hlatshwayo, V.; Saha, S.T.; Kaur, M.; Motadi, L.R. Anticancer activity, apoptosis and a structure-activity analysis of a series of 1,4-naphthoquinone-2,3-bis-sulfides. Investig. New Drugs 2019, 1-13. [CrossRef]

102. Jaufurally, A.S.; Teixeira, A.R.S.; Hollande, L.; Allais, F.; Ducrot, P.-H. Optimization of the laccase-catalyzed synthesis of ( \pm )-syringaresinol and study of its thermal and antiradical activities. ChemistrySelect 2016, 1, 5165-5171. [CrossRef]

103. Verma, A.; Shirkot, P.; Dhiman, K.; Sharma, R.; Chauhan, A. First Evidence of a Potential Antimicrobial Activity of Bacterial Laccase Against Various Plant Pathogens. Natl. Acad. Sci. Lett. 2019, 42, 5-8. [CrossRef]

104. Zhang, G.Q. A laccase with anti-proliferative activity against tumor cells from a white root fungus Abortiporus biennis. Process. Biochem. 2011, 46, 2336-2340. [CrossRef]

105. Morel, O.J.X.; Christie, R.M. Current trends in the chemistry of permanent hair dyeing. Chem. Rev. 2011, 111, 2537-2561. [CrossRef] [PubMed]

106. Otsuka Saito, K.; Ikeda, R.; Endo, K.; Tsujino, Y.; Takagi, M.; Tamiya, E. Isolation of a novel alkaline-induced laccase from Flammulina velutipes and its application for hair coloring. J. Biosci. Bioeng. 2012, 113, 575-579. [CrossRef] [PubMed]

107. Shin, S.K.; Hyeon, J.E.; Joo, Y.C.; Jeong, D.W.; You, S.K.; Han, S.O. Effective melanin degradation by a synergistic laccase-peroxidase enzyme complex for skin whitening and other practical applications. Int. J. Biol. Macromol. 2019, 129, 181-186. [CrossRef] [PubMed]

108. Rodríguez-Couto, S. Laccases for denim bleaching: An eco-friendly alternative. Open Text. J. 2012, 5, 1-7. [CrossRef]

109. Campos, R.; Kandelbauer, A.; Robra, K.H.; Cavaco-Paulo, A.; Gübitz, G.M. Indigo degradation with purified laccases from Trametes hirsuta and Sclerotium rolfsii. J. Biotechnol. 2001, 89, 131-139. [CrossRef]

110. Sondhi, S.; Kaur, R.; Kaur, S.; Kaur, P.S. Immobilization of laccase-ABTS system for the development of a continuous flow packed bed bioreactor for decolorization of textile effluent. Int. J. Biol. Macromol. 2018, 117, 1093-1100. [CrossRef] [PubMed]

111. Salami, F.; Habibi, Z.; Yousefi, M.; Mohammadi, M. Covalent immobilization of laccase by one pot three component reaction and its application in the decolorization of textile dyes. Int. J. Biol. Macromol. 2018, 120, 144-151. [CrossRef] 
112. Antecka, K.; Zdarta, J.; Siwińska-Stefańska, K.; Sztuk, G.; Jankowska, E.; Oleskowicz-Popiel, P.; Jesionowski, T. Synergistic Degradation of dye wastewaters using binary or ternary oxide systems with immobilized laccase. Catalysts 2018, 8, 402. [CrossRef]

113. Mandic, M.; Djokic, L.; Nikolaivits, E.; Prodanovic, R.; O'Connor, K.; Jeremic, S.; Topakas, E.; Nikodinovic-Runic, J. Identification and Characterization of New Laccase Biocatalysts from Pseudomonas Species Suitable for Degradation of Synthetic Textile Dyes. Catalysts 2019, 9, 629. [CrossRef]

114. Lam, Y.; Ho, Y.; He, L.; Wang, X.; Xin, J.H. Laccase-Catalyzed Biomimetic Coloration of Wool Fabrics with Phenols. AATCC J. Res. 2019, 6, 41-44. [CrossRef]

115. Su, J.; Noro, J.; Silva, S.; Fu, J.; Wang, Q.; Ribeiro, A.; Silva, C.; Cavaco-Paulo, A. Antimicrobial coating of textiles by laccase in situ polymerization of catechol and p-phenylenediamine. React. Funct. Polym. 2019, 136, 25-33. [CrossRef]

116. Zhang, T.; Bai, R.; Shen, J.; Wang, Q.; Wang, P.; Yuan, J.; Fan, X. Laccase-catalyzed polymerization of diaminobenzenesulfonic acid for $\mathrm{pH}$-responsive color-changing and conductive wool fabrics. Text. Res. J. 2018, 88, 2258-2266. [CrossRef]

117. Prajapati, C.D.; Smith, E.; Kane, F.; Shen, J. Laccase-catalysed coloration of wool and nylon. Color Technol. 2018, 134, 423-439. [CrossRef]

118. Tzanov, T.; Basto, C.; Gübitz, G.M.; Cavaco-Paulo, A. Laccases to improve the whiteness in a conventional bleaching of cotton. Macromol. Mater. Eng. 2003, 288, 807-810. [CrossRef]

119. Pereira, L.; Bastos, C.; Tzanov, T.; Cavaco-Paulo, A.; Guebitz, G.M. Environmentally friendly bleaching of cotton using laccases. Environ. Chem. Lett. 2005, 3, 66-69. [CrossRef]

120. Viswanath, B.; Rajesh, B.; Janardhan, A.; Kumar, A.P.; Narasimha, G. Fungal laccases and their applications in bioremediation. Enz. Res. 2014, 2014, 21. [CrossRef]

121. Bilal, M.; Rasheed, T.; Nabeel, F.; Iqbal, H.M.N.; Zhao, Y. Hazardous contaminants in the environment and their laccase-assisted degradation-A review. J. Environ. Manag. 2019, 234, 253-264. [CrossRef]

122. Barrios-Estrada, C.; de Jesús Rostro-Alanis, M.; Muñoz-Gutiérrez, B.D.; Iqbal, H.M.N.; Kannan, S.; Parra-Saldívar, R. Emergent contaminants: Endocrine disruptors and their laccase-assisted degradation-A review. Sci. Total Environ. 2018, 612, 1516-1531. [CrossRef]

123. Chen, X.; Zhou, Q.; Liu, F.; Peng, Q.; Teng, P. Removal of nine pesticide residues from water and soil by biosorption coupled with degradation on biosorbent immobilized laccase. Chemosphere 2019, 233, 49-56. [CrossRef] [PubMed]

124. Mishra, A.; Kumar, S.; Bhatnagar, A. Chapter 7-Potential of fungal laccase in decolorization of synthetic dyes. In Microbial Wastewater Treatment; Shah, M.P., Rodriguez-Couto, S., Eds.; Elsevier: Amsterdam, The Netherlands, 2019; pp. 127-151.

125. Zhang, R.; Wang, L.; Han, J.; Wu, J.; Li, C.; Ni, L.; Wang, Y. Improving laccase activity and stability by HKUST-1 with cofactor via one-pot encapsulation and its application for degradation of bisphenol A. J. Hazard. Mater. 2020, 383, 121130. [CrossRef] [PubMed]

126. Alharbi, S.K.; Nghiem, L.D.; van de Merwe, J.P.; Leusch, F.D.L.; Asif, M.B.; Hai, F.I.; Price, W.E. Degradation of diclofenac, trimethoprim, carbamazepine, and sulfamethoxazole by laccase from Trametes versicolor: Transformation products and toxicity of treated effluent. Biocatal. Biotransformation 2019, 37, 399-408. [CrossRef]

127. Kwiatos, N.; Jędrzejczak-Krzepkowska, M.; Strzelecki, B.; Bielecki, S. Improvement of efficiency of brown coal biosolubilization by novel recombinant Fusarium oxysporum laccase. AMB Express 2018, 8, 133. [CrossRef] [PubMed]

128. Wierckx, N.; Narancic, T.; Eberlein, C.; Wei, R.; Drzyzga, O.; Magnin, A.; Ballerstedt, H.; Kenny, S.T.; Pollet, E.; Avérous, L.; et al. Plastic Biodegradation: Challenges and Opportunities. In Consequences of Microbial Interactions with Hydrocarbons, Oils, and Lipids: Biodegradation and Bioremediation; Steffan, R., Ed.; Springer International Publishing: Cham, Switzerland, 2018; pp. 1-29.

129. Debaste, F.; Flahaut, S.; Penninckx, M.; Songulashvili, G. Using laccases for food preservation. In Food Packaging and Preservation; Academic Press: Cambridge, MA, USA, 2018; pp. 501-541. [CrossRef]

130. Osma, J.F.; Toca-Herrera, J.L.; Rodríguez-Couto, S. Uses of Laccases in the Food Industry. Enzyme Res. 2010, 2010. [CrossRef] [PubMed]

131. Piscitelli, A.; Amore, A.; Faraco, V. Last Advances in Synthesis of Added Value Compounds and Materials by Laccase mediated Biocatalysis. Curr. Org. Chem. 2012, 16, 2508-2524. [CrossRef] 
132. Ma, H.; Forssell, P.; Partanen, R.; Buchert, J.; Boer, H. Improving laccase catalyzed cross-linking of whey protein isolate and their application as emulsifiers. J. Agric. Food Chem. 2011, 59, 1406-1414. [CrossRef]

133. Mihajlovic, L.; Radosavljevic, J.; Nordlund, E.; Krstic, M.; Bohn, T.; Smit, J.; Buchert, J.; Cirkovic Velickovic, T. Peanut protein structure, polyphenol content and immune response to peanut proteins in vivo are modulated by laccase. Food Funct. 2016, 7, 2357-2366. [CrossRef]

134. Liu, X.; Kokare, C. Chapter 11-Microbial Enzymes of Use in Industry. In Biotechnology of Microbial Enzymes; Brahmachari, G., Ed.; Academic Press: Cambridge, MA, USA, 2017; pp. 267-298.

135. Rodríguez-Delgado, M.M.; Alemán-Nava, G.S.; Rodríguez-Delgado, J.M.; Dieck-Assad, G.; Martínez-Chapa, S.O.; Barceló, D.; Parra, R. Laccase-based biosensors for detection of phenolic compounds. TrAC Trends Anal. Chem. 2015, 74, 21-45. [CrossRef]

136. Castrovilli, M.C.; Bolognesi, P.; Chiarinelli, J.; Avaldi, L.; Calandra, P.; Antonacci, A.; Scognamiglio, V. The convergence of forefront technologies in the design of laccase-based biosensors-An update. TrAC Trends Anal. Chem. 2019, 119, 115615. [CrossRef]

137. Maleki, N.; Kashanian, S.; Nazari, M.; Shahabadi, N. A novel sensitive laccase biosensor using gold nanoparticles and poly L-arginine to detect catechol in natural water. Biotechnol. Appl. Biochem. 2019. [CrossRef] [PubMed]

138. Coelho, J.H.; Eisele, A.P.P.; Valezi, C.F.; Mattos, G.J.; Schirmann, J.G.; Dekker, R.F.H.; Barbosa-Dekker, A.M.; Sartori, E.R. Exploring the exocellular fungal biopolymer botryosphaeran for laccase-biosensor architecture and application to determine dopamine and spironolactone. Talanta 2019, 204, 475-483. [CrossRef] [PubMed]

139. Mohtar, L.G.; Aranda, P.; Messina, G.A.; Nazareno, M.A.; Pereira, S.V.; Raba, J.; Bertolino, F.A. Amperometric biosensor based on laccase immobilized onto a nanostructured screen-printed electrode for determination of polyphenols in propolis. Microchem. J. 2019, 144, 13-18. [CrossRef]

140. Wang, A.; Ding, Y.; Li, L.; Duan, D.; Mei, Q.; Zhuang, Q.; Cui, S.; He, X. A novel electrochemical enzyme biosensor for detection of $17 \beta$-estradiol by mediated electron-transfer system. Talanta 2019, 192, 478-485. [CrossRef]

141. Campaña, A.L.; Florez, S.L.; Noguera, M.J.; Fuentes, O.P.; Ruiz Puentes, P.; Cruz, J.C.; Osma, J.F. Enzyme-Based Electrochemical Biosensors for Microfluidic Platforms to Detect Pharmaceutical Residues in Wastewater. Biosensors 2019, 9, 41. [CrossRef]

142. Mano, N.; de Poulpiquet, A. O2 Reduction in Enzymatic Biofuel Cells. Chem. Rev. 2018, 118, $2392-2468$. [CrossRef]

143. Khan, H.; Kim, C.M.; Kim, S.Y.; Goel, S.; Dwivedi, P.K.; Sharma, A.; Kim, Y.H.; Kim, G.M. Fabrication of Enzymatic Biofuel Cell with Electrodes on Both Sides of Microfluidic Channel. Int. J. Precis. Manuf. Green Technol. 2019, 6, 511-520. [CrossRef]

144. Kang, S.; Yoo, K.S.; Chung, Y.; Kwon, Y. Cathodic biocatalyst consisting of laccase and gold nanoparticle for improving oxygen reduction reaction rate and enzymatic biofuel cell performance. Ind. Eng. Chem. 2018, 62, 329-332. [CrossRef]

145. Ghosh, B.; Saha, R.; Bhattacharya, D.; Mukhopadhyay, M. Laccase and its source of sustainability in an enzymatic biofuel cell. Bioresour. Technol. Rep. 2019, 6, 268-278. [CrossRef]

146. Zhang, L.; Cui, H.; Zou, Z.; Garakani, T.M.; Novoa-Henriquez, C.; Jooyeh, B.; Schwaneberg, U. Directed Evolution of a Bacterial Laccase (CueO) for Enzymatic Biofuel Cells. Angew. Chem. 2019, 131, 4610-4613. [CrossRef]

147. Lopes, P.; Koschorreck, K.; Nedergaard Pedersen, J.; Ferapontov, A.; Lörcher, S.; Skov Pedersen, J.; Urlacher, V.B.; Ferapontova, E.E. Bacillus Licheniformis CotA laccase mutant: Electrocatalytic reduction of $\mathrm{O} 2$ from $0.6 \mathrm{~V}$ (SHE) at $\mathrm{pH} 8$ and in seawater. ChemElectroChem 2019, 6, 2043-2049. [CrossRef]

148. Li, X.; Lv, P.; Yao, Y.; Feng, Q.; Mensah, A.; Li, D.; Wei, Q. A novel single-enzymatic biofuel cell based on highly flexible conductive bacterial cellulose electrode utilizing pollutants as fuel. Chem. Eng. J. 2020, 379, 122316. [CrossRef]

149. Walde, P.; Kashima, K.; Ćirić-Marjanović, G. Synthesizing Polyaniline With Laccase/O2 as Catalyst. Front. Bioeng. Biotechnol. 2019, 7. [CrossRef] [PubMed]

150. Fodor, C.; Gajewska, B.; Rifaie-Graham, O.; Apebende, E.A.; Pollard, J.; Bruns, N. Laccase-catalyzed controlled radical polymerization of $\mathrm{N}$-vinylimidazole. Polym. Chem. 2016, 7, 6617-6625. [CrossRef] 
151. Scheibel, D.M.; Gitsov, I. Unprecedented Enzymatic Synthesis of Perfectly Structured Alternating Copolymers via "Green" Reaction Cocatalyzed by Laccase and Lipase Compartmentalized within Supramolecular Complexes. Biomacromolecules 2019, 20,927-936. [CrossRef]

152. Li, F.; Yu, Y.; Wang, Q.; Yuan, J.; Wang, P.; Fan, X. Polymerization of dopamine catalyzed by laccase: Comparison of enzymatic and conventional methods. Enzym. Microb. Technol. 2018, 119, 58-64. [CrossRef]

153. Permana, D.; Minamihata, K.; Goto, M.; Kamiya, N. Laccase-catalyzed bioconjugation of tyrosine-tagged functional proteins. J. Biosci. Bioeng. 2018, 126, 559-566. [CrossRef]

154. Permana, D.; Minamihata, K.; Tatsuke, T.; Lee, J.M.; Kusakabe, T.; Goto, M.; Kamiya, N. Polymerization of Horseradish Peroxidase by a Laccase-Catalyzed Tyrosine Coupling Reaction. Biotechnol. J. 2019, 14, 1800531. [CrossRef]

155. Karaki, N.; Aljawish, A.; Muniglia, L.; Bouguet-Bonnet, S.; Leclerc, S.; Paris, C.; Jasniewski, J.; Humeau-Virot, C. Functionalization of pectin with laccase-mediated oxidation products of ferulic acid. Enzym. Microb. Technol. 2017, 104, 1-8. [CrossRef]

156. Bai, R.; Yu, Y.; Wang, Q.; Fan, X.; Wang, P.; Yuan, J.; Shen, J. Laccase-catalyzed poly(ethylene glycol)-templated 'zip' polymerization of caffeic acid for functionalization of wool fabrics. J. Clean. Prod. 2018, 191, 48-56. [CrossRef]

157. Bu, X.; Pei, J.; Zhang, F.; Liu, H.; Zhou, Z.; Zhen, X.; Wang, J.; Zhang, X.; Chan, H. The hydration mechanism and hydrogen bonding structure of 6-carboxylate chitooligosaccharides superabsorbent material prepared by laccase/TEMPO oxidation system. Carbohydr. Polym. 2018, 188, 151-158. [CrossRef] [PubMed]

158. Dong, A.; Fan, X.; Wang, Q.; Yu, Y.; Cavaco-Paulo, A. Hydrophobic surface functionalization of lignocellulosic jute fabrics by enzymatic grafting of octadecylamine. Int. J. Biol. Macromol. 2015, 79, 353-362. [CrossRef] [PubMed]

159. Jiang, J.; Ye, W.; Yu, J.; Fan, Y.; Ono, Y.; Saito, T.; Isogai, A. Chitin nanocrystals prepared by oxidation of $\alpha$-chitin using the O2/laccase/TEMPO system. Carbohydr. Polym. 2018, 189, 178-183. [CrossRef] [PubMed]

160. Parikka, K.; Nikkilä, I.; Pitkänen, L.; Ghafar, A.; Sontag-Strohm, T.; Tenkanen, M. Laccase/TEMPO oxidation in the production of mechanically strong arabinoxylan and glucomannan aerogels. Carbohydr. Polym. 2017, 175, 377-386. [CrossRef] [PubMed]

161. Schirmann, J.G.; Dekker, R.F.H.; Borsato, D.; Barbosa-Dekker, A.M. Selective control for the laccase-catalyzed synthesis of dimers from 2,6-dimethoxyphenol: Optimization of 3,3',5,5'-tetramethoxy-biphenyl-4,4'-diol synthesis using factorial design, and evaluation of its antioxidant action in biodiesel. Appl. Catal. A 2018, 555, 88-97. [CrossRef]

162. Slagman, S.; Escorihuela, J.; Zuilhof, H.; Franssen, M.C.R. Characterization of the laccase-mediated oligomerization of 4-hydroxybenzoic acid. RSC Adv. 2016, 6, 99367-99375. [CrossRef]

163. Zerva, A.; Manos, N.; Vouyiouka, S.; Christakopoulos, P.; Topakas, E. Bioconversion of Biomass-Derived Phenols Catalyzed by Myceliophthora thermophila Laccase. Molecules 2016, 21, 550. [CrossRef]

164. Su, J.; Noro, J.; Fu, J.; Wang, Q.; Silva, C.; Cavaco-Paulo, A. Exploring PEGylated and immobilized laccases for catechol polymerization. AMB Express 2018, 8, 134. [CrossRef]

165. Polak, J.; Jarosz-Wilkolazka, A. Fungal laccases as green catalysts for dye synthesis. Process. Biochem. 2012, 47, 1295-1307. [CrossRef]

166. Polak, J.; Jarosz-Wilkołazka, A.; Szałapata, K.; Grąz, M.; Osińska-Jaroszuk, M. Laccase-mediated synthesis of a phenoxazine compound with antioxidative and dyeing properties-The optimisation process. New Biotechnol. 2016, 33, 255-262. [CrossRef]

167. Polak, J.; Jarosz-Wilkolazka, A.; Szuster-Ciesielska, A.; Wlizlo, K.; Kopycinska, M.; Sojka-Ledakowicz, J.; Lichawska-Olczyk, J. Toxicity and dyeing properties of dyes obtained through laccase-mediated synthesis. J. Clean Prod. 2016, 112, 4265-4272. [CrossRef]

168. Pezzella, C.; Giacobbe, S.; Giacobelli, V.G.; Guarino, L.; Kylic, S.; Sener, M.; Sannia, G.; Piscitelli, A. Green routes towards industrial textile dyeing: A laccase based approach. J. Mol. Catal. B Enzym. 2016, 134, 274-279. [CrossRef]

169. Sousa, A.C.; Piedade, M.F.M.M.; Martins, L.O.; Robalo, M.P. Eco-friendly synthesis of indo dyes mediated by a bacterial laccase. Green Chem. 2016, 18, 6063-6070. [CrossRef]

170. Giacobelli, V.G.; Pezzella, C.; Sannia, G.; Olivieri, G.; Fontanarosa, C.; Amoresano, A.; Piscitelli, A. Laccase-based synthesis of SIC-RED: A new dyeing product for protein gel staining. Biocatal. Agric. Biotechnol. 2018, 15, 270-276. [CrossRef] 
171. Su, J.; Noro, J.; Fu, J.; Wang, Q.; Silva, C.; Cavaco-Paulo, A. Coloured and low conductive fabrics by in situ laccase-catalysed polymerization. Process. Biochem. 2019, 77, 77-84. [CrossRef]

172. Dhand, C.; Harini, S.; Venkatesh, M.; Dwivedi, N.; Ng, A.; Liu, S.; Verma, N.K.; Ramakrishna, S.; Beuerman, R.W.; Loh, X.J.; et al. Multifunctional Polyphenols- and Catecholamines-Based Self-Defensive Films for Health Care Applications. ACS Appl. Mater. Interfaces 2016, 8, 1220-1232. [CrossRef]

173. Bersanetti, P.A.; Escobar, V.H.; Nogueira, R.F.; Ortega, F.D.S.; Schor, P.; Morandim-Giannetti, A.D.A. Enzymatically obtaining hydrogels of PVA crosslinked with ferulic acid in the presence of laccase for biomedical applications. Eur. Polym. J. 2019, 112, 610-618. [CrossRef]

174. Zhou, Q.; Zhang, Q.; Wang, P.; Deng, C.; Wang, Q.; Fan, X. Enhancement biocompatibility of bacterial cellulose membrane via laccase/TEMPO mediated grafting of silk fibroins. Fibers Polym. 2017, 18, 1478-1485. [CrossRef]

175. Campia, P.; Ponzini, E.; Rossi, B.; Farris, S.; Silvetti, T.; Merlini, L.; Brasca, M.; Grandori, R.; Galante, Y.M. Aerogels of enzymatically oxidized galactomannans from leguminous plants: Versatile delivery systems of antimicrobial peptides and enzymes. Carbohydr. Polym. 2017, 158, 102-111. [CrossRef]

176. Silvetti, T.; Merlini, L.; Brasca, M.; Galante, Y.M. Aerogel from chemo-enzymatically oxidized fenugreek gum: An innovative delivery system of isothiazolinones biocides. Appl. Microbiol. Biotechnol. 2018, 102, 2683-2692. [CrossRef]

177. Huber, D.; Tegl, G.; Baumann, M.; Sommer, E.; Gorji, E.G.; Borth, N.; Schleining, G.; Nyanhongo, G.S.; Guebitz, G.M. Chitosan hydrogel formation using laccase activated phenolics as cross-linkers. Carbohydr. Polym. 2017, 157, 814-822. [CrossRef] [PubMed]

178. Mattinen, M.L.; Valle-Delgado, J.J.; Leskinen, T.; Anttila, T.; Riviere, G.; Sipponen, M.; Paananen, A.; Lintinen, K.; Kostiainen, M.; Österberg, M. Enzymatically and chemically oxidized lignin nanoparticles for biomaterial applications. Enzym. Microb. Technol. 2018, 111, 48-56. [CrossRef] [PubMed]

179. Li, H.; Hou, J.; Duan, L.; Ji, C.; Zhang, Y.; Chen, V. Graphene oxide-enzyme hybrid nanoflowers for efficient water soluble dye removal. J. Hazard. Mater. 2017, 338, 93-101. [CrossRef] [PubMed]

180. Chauhan, P.S.; Kumarasamy, M.; Sosnik, A.; Danino, D. Enhanced thermostability and anticancer activity in breast cancer cells, of laccase immobilized on Pluronic@-stabilized nanoparticles. ACS Appl. Mater. Interfaces 2019, 11, 39436-39448. [CrossRef] [PubMed]

181. Jasim, A. Medicinal properties of laccase from Basidiomycetes mushroom: A review. Adv. Life Sci. Technol. 2017, 54, 99-109.

(C) 2019 by the authors. Licensee MDPI, Basel, Switzerland. This article is an open access article distributed under the terms and conditions of the Creative Commons Attribution (CC BY) license (http://creativecommons.org/licenses/by/4.0/). 